\title{
A Lean Approach to Developing Sustainable Supply Chains
}

\author{
Carina L. Gargalo ${ }^{1}$, Eduardo Pereda Pons ${ }^{2}$, Ana Paula Barbosa-Povoa ${ }^{2}$ and Ana Carvalho ${ }^{2, *(D)}$ \\ 1 Process and Systems Engineering Center (PROSYS), Department of Chemical and Biochemical Engineering, \\ Technical University of Denmark, 2800 Kgs. Lyngby, Denmark; carlour@kt.dtu.dk \\ 2 Centre for Management Studies (CEG-IST), Instituto Superior Técnico, University of Lisbon, \\ 1649004 Lisbon, Portugal; ed.pereda93@gmail.com (E.P.P.); apovoa@tecnico.ulisboa.pt (A.P.B.-P.) \\ * Correspondence: anacarvalho@tecnico.ulisboa.pt
}

Citation: Gargalo, C.L.; Pereda Pons, E.; Barbosa-Povoa, A.P.; Carvalho, A. A Lean Approach to Developing Sustainable Supply Chains. Sustainability 2021, 13, 3714. https:// doi.org/10.3390/su13073714

Academic Editor: Alessio Ishizaka

Received: 4 December 2020

Accepted: 22 March 2021

Published: 26 March 2021

Publisher's Note: MDPI stays neutral with regard to jurisdictional claims in published maps and institutional affiliations.

Copyright: (c) 2021 by the authors. Licensee MDPI, Basel, Switzerland. This article is an open access article distributed under the terms and conditions of the Creative Commons Attribution (CC BY) license (https:// creativecommons.org/licenses/by/ $4.0 /)$.

\begin{abstract}
Corporations and their supply chains have to go through significant changes to become more sustainable as society is pressing for sustainable systems. To this end, it is critical to develop new methodologies to trim away processes and activities that add no value and, thus, derive more sustainable supply chains. Considering the need to have a simple tool that can be used by managers to achieve this goal, in this work, we explore the value stream mapping method (VSM) and extend it to support the design of sustainable supply chains in a more systematic and quantitative way. This work proposes a new generic methodology, called SustainSC-VSM, which allows assessing the supply chain's performance through a set of realistic indicators. These indicators are designed to identify bottlenecks that hinder sustainable operations development and provide guidelines to achieve that goal by following a lean-driven sustainability approach. SustainSC-VSM was tested and validated through its application to a relevant industrial case study, where operational bottlenecks were pinpointed and potential solutions were identified to seek continuous improvement. Although envisioned to be generic and applicable to all supply chains, the indicators should be selected according to the context in study (e.g., services). SustainSC-VSM aims at being a generic and systematic tool to design future value stream maps to achieve a more sustainable supply chain following a lean-driven sustainability approach, through the use of multi-dimensional and multidisciplinary indicators to identify and solve the supply chain's bottlenecks.
\end{abstract}

Keywords: supply chain; value stream mapping; sustainability; lean

\section{Introduction}

Worldwide stressors, such as climate change and a consciousness of social and environmental responsibilities, along with stronger competition and lower profit margins, have been forcing companies to vigorously act to maintain their competitiveness and to commit to sustainable practices and performance management $[1,2]$. Both academics and industries are motivated to find the best way to simultaneously include all three aspects of sustainability (economic, environmental and social) to achieve meaningful and beneficial results. Lean management has proven to be a handy and innovative tool to promote continuous improvement, and to be easily adaptable to include sustainability aspects [1]. It is an evolving methodology that targets the highest quality, profitability and customer service level, at the lowest possible costs, in a prompt fashion, through the continuous reduction in waste regarding value-added and non-value-added operations [3]. The unavoidable effect of evolving drivers over the years, such as expanded business networks and customer needs and demands, has motivated the change in focus to the supply chain management level [1,4-6]. "(SCM) encompasses the planning and management of all activities involved in sourcing and procurement, conversion, and logistics management activities" [7]. Lean management has been broadened to include all the actors of the supply chain. In this context, Vonderembse et al. [8] described "lean supply chain" as the "continuous improvement of efforts that target the reduction of waste and non-value-added activities along 
the value chain." Thus, from the sustainability angle, it has been proven that it is impossible to observe environmental and social policies and preserve competitiveness without collaboration among supply chain actors [1,9]. Due to the ongoing interest and need to implement corporate environmental and social policies, combining lean management and sustainability has become more popular. An increasing number of studies have proven that there are clear positive impacts (economic, environmental and social) on the supply chain performance when lean is linked to sustainability [10]. Intensive research has been conducted on the interaction and the pursuit of sustainability, application of lean management and supply chain management practices. Since one of the lean operational goals is to keep or improve the production quality but reduce the use of resources, lean principles lead to more environmentally friendly operations due to lower waste produced and thus lower environmental impact. By reducing the quantity of materials used, the costs are also reduced, and therefore sustainability's economic facet is likewise addressed. Increasing quality and efficiency leads to water and energy consumption improvements, which also gets reflected in the costs. Henceforth, by implementing the lean principles, one also achieves the main sustainability goals. More and more research has been suggesting the substantial overlap, similarities and synergies between these two concepts and how to use them [11].

Table 1 summarizes the most relevant and popular lean tools developed over the years that attempt to tackle this issue of combining these two concepts: thriving towards sustainability by applying lean principles. Notwithstanding, and as documented in Table 1, many studies have focused on developing tools that are usually based on qualitative models and, more specifically, operations. Improvements towards sustainable supply chains have not been widely explored in the literature and process bottlenecks have been identified in a qualitative way, which leads to missing some important critical points and misleading actions. There is an overall lack of generic, systematic and quantitative approaches to tackle supply chain bottlenecks and point out ways to overcome these matters towards more sustainable supply chains. Therefore, the following research question (RQ) can be formulated and will be answered by this work:

RQ: How can a value stream mapping (VSM) methodology be extended to sustainable supply chain management analysis, so that bottlenecks can be identified and improved in a systematic, accurate and quantitative way?

Henceforth, this work differs from the previous studies in the field by proposing a new methodology called SustainSC-VSM, whose goal is to systematically combine sustainability, lean philosophy and supply chain management into a holistic, quantitative and qualitative methodology. SustainSC-VSM is a systematic tool that measures the supply chain performance and provides guidelines to attain a more sustainable supply chain following a lean-driven sustainability approach by guiding the manager through the steps needed to trim away processes and operations that add no value to the whole value chain. This work introduces the following novel contributions:

(i) Proposes a new methodology, which integrates the extended VSM (EVSM) [12] methodology with SustainPro's systematic approach [13];

(ii) Introduces new multi-disciplinary qualitative and quantitative indicators that represent and analyze all facets of sustainability to measure the supply chain performance;

(iii) Through the use of indicators, the whole supply chain is assessed in terms of the three pillars of sustainability. The assessment of materials and information flows between the supply chain actors is performed;

(iv) Identifies, in a quantitative way, the supply chain's bottlenecks, as well as providing potential solutions, prioritization of actions and recommendations to overcome the identified bottlenecks;

(v) Facilitates creating future value stream maps to attain a (more) sustainable supply chain. 
Table 1. Lean tools and contributions towards sustainable development (SD) in chronological order. Adapted and extended from [1,14].

\begin{tabular}{|c|c|c|}
\hline Tool & References & Brief Description \\
\hline $5 S$ & [15] & $\begin{array}{ll}\text { - } & \begin{array}{l}\text { Encourages a clean and organized work } \\
\text { environment (econ, env, soc) }\end{array} \\
\text { - } & \text { Reduces health and safety risks and space } \\
\text { needed for operations (econ, soc) } \\
\text { - } \quad \text { Increases job satisfaction rate (soc) }\end{array}$ \\
\hline Kaizen & [16] & $\begin{array}{l}\text { - Finds opportunities for continuous improvement } \\
\text { and waste reduction (env, econ) } \\
\text { Reduces environmental impacts and health } \\
\text { hazards inside or outside the production } \\
\text { boundaries (env) }\end{array}$ \\
\hline
\end{tabular}

- $\quad$ Applied at the factory level (operations)

- Visual tool to improve information and material flows (econ)

- Used to obtain a roadmap for improvement by

VSM $\quad[17,18]$ mapping the current and future value streams (track value-added and non-value-added operations) (econ)

- Promotes waste elimination (econ, env)

- Helps in tracking and eliminating avoidable and/or unnecessary use of resources (econ, env) Extended VSM
(EVSM)

Kanban and Visual Factory

Visual

Management

(Andon)
- $\quad$ Extension of the VSM tool to the supply chain context (see points mentioned in lean tool VSM) (econ, env, soc)

- Deals with excessive inventory (the most prejudicial form of waste) (econ, env)

- Enables good flow of information and items along the supply chain-some studies mention that it can augment the consumption of energy and water (econ, env)

- Visual factory means the use of codes to promote good communication (econ, env, soc)

- $\quad$ Facilitates the reduction in waste and good work environment (econ, env, soc)

- $\quad$ Based on feedback alerts to control undesirable situations (econ, env, soc)

- It provides real-time communication to avoid the propagation of problems along the value chain-associated with effective reduction in waste of resources (econ, env, soc)

- Reduction in environmental waste and hazard (econ, env)

- It could be used as alert mechanism for environmental management (env) 
Table 1. Cont.

\begin{tabular}{|c|c|c|}
\hline Tool & References & Brief Description \\
\hline $\begin{array}{l}\text { Total Productive } \\
\text { Mainte- } \\
\text { nance(TPM) }\end{array}$ & [21] & $\begin{array}{l}\text { - Aims to decrease cycle times and reduce defected } \\
\text { production and health risks by proactive } \\
\text { maintenance (econ, env, soc) } \\
\text { Targets to increase production efficiency to } \\
\text { reduce the amount of resources used and to } \\
\text { avoid wastes (econ, env) } \\
\text { By applying preventive and proactive } \\
\text { maintenance, it increases equipment life span } \\
\text { and can be used to detect the need for the } \\
\text { improvement of technology (econ, env) }\end{array}$ \\
\hline $\begin{array}{l}\text { Single Minute } \\
\text { Exchange of Dies } \\
\text { (SMED) }\end{array}$ & {$[22,23]$} & $\begin{array}{l}\text { Targets the reduction in changeover times by } \\
\text { simplifying operations, reduction in or } \\
\text { eradication of redundant tasks and work } \\
\text { standardization. Systems become more } \\
\text { responsive and with lower inventory levels } \\
\text { (econ, env) } \\
\text { The goal is to reduce the changeover times to } \\
\text { "single" digits (econ, env) } \\
\text { Potential reduction in emissions and hazardous } \\
\text { chemicals (env) } \\
\text { Lower manufacturing costs (less equipment } \\
\text { downtime), lower inventory levels and better } \\
\text { responsiveness to customer demand (econ, env) }\end{array}$ \\
\hline
\end{tabular}

- Investigates abnormality, determines root cause and promotes corrective actions (econ, env)

Jidoka

(Autonomation)

[24]

Just-in-time (JIT)

[25]

Sustainable-VSM

[26-29]

Green VSM

[30]
- Contributes to economic sustainability and waste reduction by eliminating or reducing labor, material and energy usage (costs) (econ, env)

- $\quad$ Lower health and safety issues (soc)

- $\quad$ Provides reduced inventories, increased liquidity and reduced space requirements (econ, env)

- Lower inventories decreases the environmental impact and economic sustainability (econ, env)

- $\quad$ Based upon the VSM tool, extended to include environmental, social and sustainable manufacturing metrics (econ, env, soc)

- Used to pinpoint value-adding and non-value-adding operations (econ, env)

- $\quad$ Extension of the VSM tool context (see points mentioned in lean tool VSM) (econ, env, soc)

- It has the characteristics of VSM and additional

Kaizan features (econ)

- Uses a preventive strategy regarding processes, products and services (econ, env, soc)

- Aims at increased overall efficiency and reduced social and environmental risks (econ, env, soc) 
Table 1. Cont.

\begin{tabular}{lll}
\hline \multicolumn{1}{c}{ Tool } & References & \multicolumn{1}{c}{ Brief Description } \\
\hline & $\bullet$ & $\begin{array}{l}\text { Extension of the VSM tool (see points mentioned } \\
\text { in lean tool VSM) (econ, env, soc) } \\
\text { It enables the visualization of an integrated } \\
\text { structure of the resources usage (econ, env) } \\
\text { Environmental }\end{array}$ \\
VSM & - $\begin{array}{l}\text { Mapping strategy applied to align the economic } \\
\text { and environmental aspects in production } \\
\text { processes (econ, env) }\end{array}$ \\
&
\end{tabular}

\begin{tabular}{|c|c|c|}
\hline $\begin{array}{l}\text { Energy Value } \\
\text { Stream Mapping }\end{array}$ & {$[32,33]$} & $\begin{array}{l}\text { Extension of the VSM tool, including energy } \\
\text { components (see points mentioned in lean tool } \\
\text { VSM) (econ, env, soc) } \\
\text { Identifies the level of energy use and wastage in } \\
\text { each step and points out the opportunities for } \\
\text { energy savings (non-value-added energy } \\
\text { consumption) (econ, env) } \\
\text { Leads to the development of a future value } \\
\text { stream map taking into account the energy and } \\
\text { cost assessment (econ, env) } \\
\text { Aids the division of operations and process steps } \\
\text { into value- and non-value-added activities (econ, } \\
\text { env, soc) }\end{array}$ \\
\hline $\begin{array}{l}\text { EPA Lean and } \\
\text { Energy Toolkit }\end{array}$ & [34] & $\begin{array}{l}\text { Implements practical strategies and practices to } \\
\text { enhance lean results while cultivating energy } \\
\text { efficiency and reduction in greenhouse gas } \\
\text { emissions, costs and risks (econ, env) }\end{array}$ \\
\hline $\begin{array}{l}\text { EPA Lean and } \\
\text { Environment } \\
\text { Toolkit }\end{array}$ & [35] & $\begin{array}{l}\text { - It is developed and used by the EPA to improve } \\
\text { environmental results, reduce business costs and } \\
\text { risks and identify and eliminate waste (econ, env, } \\
\text { soc) }\end{array}$ \\
\hline
\end{tabular}

$\overline{\text { Econ: it contributes to the economic pillar of sustainability; env: it contributes to the environmental pillar of }}$ sustainability; soc: it contributes to the social pillar of sustainability.

In summary, SustainSC-VSM aims at being a generic and systematic tool that, following a lean-driven sustainability approach through the use of indicators, identifies and improves the supply chain's bottlenecks. Such tool supports the design of a value stream map that will inform decision makers to achieve a (more) sustainable supply chain.

The remainder of the manuscript is organized as follows. In Section 2, the background literature referring to the tools used to develop the SustainSC-VSM methodology is described. Section 3 describes the methodology proposed in this work. The case study description and the results of the application of the methodology are presented in Section 3. Lastly, key conclusions are drawn and "take-home" messages are formulated in Section 4.

\section{Methodology for Lean Design of Sustainable Supply Chains: SustainSC-VSM}

The main goal of this work is to propose a new generic and systematic step-by-step methodology to extend the analysis to the sustainable supply chain context, facilitating the identification of bottlenecks in a quantitative way and providing guidelines on the creation of a future value stream map, where lean principles are incorporated alongside pertinent indicators. Thus, it is targeted towards achieving a more sustainable and efficient supply chain. Figure 1 presents the proposed methodology, which is called SustainSCVSM. This new methodology incorporates two methodologies: (i) extended value stream 
mapping (EVSM) and (ii) SustainPro, further extending them to the context of sustainable supply chains.

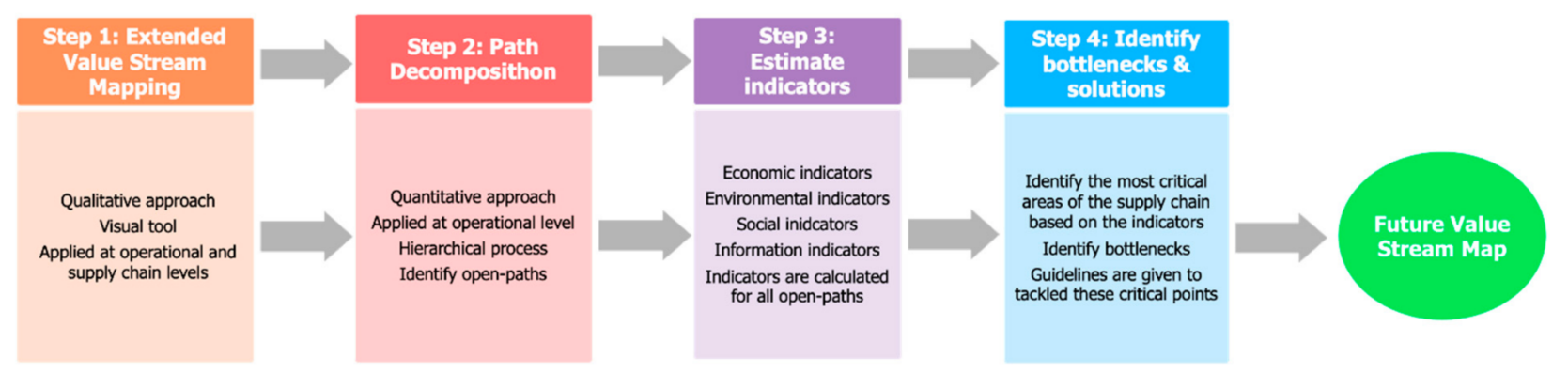

Figure 1. SustainSC-VSM methodology.

SustainSC-VSM based its roots in EVSM because, as described in Table 1, this is a useful tool to identify and screen waste in the supply chain in a qualitative way [12]. Moreover, its straightforwardness and uniform language convert EVSM into a valuable tool for managers that can be used in all kinds of supply chains. However, one of the significant limitations in EVSM analysis is the lack of an available quantitative procedure, which often leads to cumbersome tasks. Moreover, this methodology does not take into consideration the sustainability aspects, and therefore, to tackle this challenge, in the new methodology SustainSC-VSM, EVSM is combined with SustainPro.

SustainPro is a framework that incorporates an indicator-based methodology to design new sustainable alternatives in any chemical process [13]. SustainPro implements the methodology proposed by Carvalho et al. (2008) [36] and Carvalho et al. (2009a) [37]. SustainPro is able to decompose complex systems in smaller parts and assess them quantitatively. However, to cover the whole supply chain and not only the production of chemical processes, SustainPro needs to be adapted and extended to include indicators that fit sustainable supply chain purposes. The indicators integrated in SustainSC-VSM are multi-dimensional and multi-disciplinary and are designed to measure supply chain performance and effectively point out its bottlenecks.

The SustainSC-VSM steps are described in the following subsections.

\subsection{Step 1: Extended Value Stream Mapping (EVSM)}

In this step, the sequence of operations and entities within the supply chain is represented through EVSM [12]. There are eight tasks, and they are described as follows:

Task 1: Identify the product family. A product family encompasses a group of products, which follow very similar process steps. Two products that have the same or similar functionality or features are a potential example.

Task 2: Define a convenient field of view. Due to the often complex nature of the supply chain, Womack and Jones (2002) [12] proposed dividing the entire supply chain into different parts; however, they did not indicate how to do it and they did not propose any quantitative decomposition. To this end, to extend the scope of EVSM, SustainSC-VSM splits the complex structure of the supply chain into smaller areas named open paths, which are proposed in SustainPro (see Step 2, path decomposition).

Task 3: Create the work team, including all supply chain entities and companies. Note that this task is not mandatory.

Task 4: Determine the level of detail of the EVSM by setting clear system boundaries. It is essential to note that the EVSM's scale is broader than the VSM, which is limited to facility-level boundaries.

Task 5: Collect the information about the flowrates, lead times and value-added time.

Task 6: Map the backflow from the supply chain's last entity, which triggers the entire production of the upstream process. As mentioned, since the full supply chain is a complex process, it is recommended to map each entity as a single process. The different entities can 
be separated into factories, warehouses/cross-docks and retailers. Each entity is defined by its standard symbol, along with the describing data. The required data for each entity are as follows:

- Factory: (i) average time that the flow spends in the raw materials' warehouse; (ii) time that the flow is being processed; (iii) time spent in the final goods warehouse; and (iv) the ratio of defects and every part every interval (EPEI).

- Retailer: demand (daily or weekly) for each product of the family.

- Warehouse: (i) ratio of product defects; and (ii) average time that the product flow stays in the warehouse.

Task 7: Mapping of transportation using predefined symbols. It is essential to distinguish between the expected shipment, including its frequency, and the expedited shipment flow. It is necessary to represent the frequency of the rush or special orders (between the facilities). To clearly describe the shipment characteristics, the following data are required: (i) distance between entities; (ii) time between facilities; (iii) average order of shipment (batch size); and (iv) average ratio of defects of the shipment process. This information is further analyzed in Step 3 of the methodology.

Task 8: Mapping of the transport flows. This information entails: (i) the frequency of the communications; and (ii) the processing time of the information data identified by each production control department.

At the end of this step, the user can comprehensively envision the sequence of all supply chain activities. All activities, with and without value added, are pinpointed following their sequence and connection. Furthermore, after defining the current stream map, all data needed to describe the supply chain operations (see the complete set of data collected in Table 2) are collected as part of this methodology step.

Table 2. Complete set of data to be collected.

\begin{tabular}{|c|c|c|}
\hline \multicolumn{3}{|c|}{ Data } \\
\hline \multicolumn{2}{|c|}{ Entity } & \multirow[t]{2}{*}{ Path } \\
\hline Factory/Warehouse & Transport & \\
\hline Price Utility & Price Utility & Price Product \\
\hline Energy Consumption & Energy Consumption & Price Raw Material \\
\hline Inventory & Lead Time & Costumer Demand \\
\hline Holding Cost & Defective Flow & On Time \\
\hline Lead Time & Carbon Footprint & Theoretical Flow \\
\hline Demand & Green Energy Consumption & Due Date for Delivery \\
\hline Defective Flow & Number of Incidents & Earliest Due Date \\
\hline Process Capacity & Employees & Variance of Lead Time \\
\hline Carbon Footprint & Number of Lawsuits & Variance of Demand \\
\hline Waste & Waste & Variance of Mass Flow \\
\hline Green Energy Consumption & Lower Salary & Penalty Rate \\
\hline Number Incidents & Higher Salary & \\
\hline Employees & Working Hours per Year & \\
\hline Number of Lawsuits & & \\
\hline Demand Downstream Entity & & \\
\hline Lower Salary & & \\
\hline Higher Salary & & \\
\hline Working Hours per Year & & \\
\hline
\end{tabular}




\subsection{Step 2: Path Decomposition}

In this step, the supply chain network structure identified in Step 1 is decomposed by breaking it down into smaller areas to simplify the identification of bottlenecks. These smaller areas are determined by applying graph theory [38], which is implemented in SustainPro [13] and incorporated in SustainSC-VSM. Hence, all the mass and energy flow paths are split into open and closed paths for each compound in the process. The closed paths are recycled flows that start and end in the same entity. On the other hand, open paths are flows of a specific compound/part/unit with an entrance and an exit of the system. The "entrance" of a compound is due to one of two events, feed stream or production in a production facility, whereas the "exit" means that the compound gets out of the system or is consumed in a given process of the supply chain. SustainPro is used to identify all the open and closed paths and determine each path's respective flow compound/part/unit.

\subsection{Step 3: Calculate Indicators}

As previously discussed, there is a lack of systematization when integrating the different parts of the supply chain to improve operations sustainability. Furthermore, despite the guidelines proposed by [12], which steps are necessary to achieve an improved value stream map is not always evident. Thus, to lead and motivate companies to embrace sustainability, in this work, a new set of indicators is proposed to assess the supply chain paths comprehensively. The proposed indicators cover all three sustainability pillars and create a new information area to ensure optimal coordination between entities to improve performance. The indicators should cover the most popular classification, which divides the indicators into four categories: quality [39,40], time [39-41], cost [39,40,42] and flexibility $[39,43]$. The indicators are applied to all paths to carry out a comparative analysis and prioritize the retrofit actions to be taken to improve the current value stream map. Noteworthy is that most of the indicators inbuilt in the SustainSC-VSM methodology are generic and applied to the different types of supply chains covering the manufacturing, chemical process-based supply chains and service-based supply chain. The user must select from the list of indicators the ones that translate the activities of the supply chain to be studied. It often occurs that trade-offs among objectives must be made. Furthermore, companies are not recommended to improve all indicators simultaneously, since this will require high resource investment. Therefore, the SustainSC-VSM methodology aims at guiding the managers to carefully prioritize the indicators following their business goals, in order to succeed in devising a more sustainable future state value stream map. The indicators implemented in the SustainSC-VSM methodology are described in detail in the next subsections. A summary list of all indicators introduced in the proposed methodology (SustainSC-VSM) is presented in Table A1 in Appendix A.

Furthermore, the data required to estimate the economic, environmental, social and information indicators (detailed in Tables 3-9) are summarized in Table 2. The data required from the companies are data usually available in the different industries, which therefore makes it possible and easy to calculate the indicators presented in Tables 3-9.

\subsubsection{Step 3.1: Economic Indicators}

The economic indicators report financial metrics assessing if the company's resources are being well used to create value and intend to point out other potential ways to create value. In the supply chain management community, it is agreed that accomplishing the strategic goals in any supply chain implies a sound control system, including performance measurements regarding the cost, quality, time and flexibility of the supply chain $[39,40]$. Therefore, these are the subgroups into which the economic indicators are divided.

\section{Cost}

The supply chain cost is one of the most critical aspects of the supply chain's models. A competitive supply chain requires an in-depth understanding of the distribution cost. To this end, the authors propose a set of relevant indicators to assess the most relevant costs; 
they are described in Table 3. It is important to note that some of the indicators are adapted from the relevant literature, while the remaining were devised in this work.

Table 3. Economic indicators: cost.

\begin{tabular}{|c|c|c|c|c|c|}
\hline Indicator & Description & Reference & Equati & & Nomenclature \\
\hline $\begin{array}{l}\text { Material } \\
\text { Value } \\
\text { Added-SC } \\
(M V A-S C)\end{array}$ & $\begin{array}{l}\text { MVA-SC estimates the value generated } \\
\text { between the start and the endpoint of a given } \\
\text { path. This indicator is expressed in EUR, and, } \\
\text { consequently, negative values of MVA-SC } \\
\text { identify the need for changes/improvements. }\end{array}$ & $\begin{array}{l}\text { Adapted } \\
\text { from [36] } \\
\text { to the } \\
\text { supply } \\
\text { chain } \\
\text { context }\end{array}$ & $\begin{array}{c}M V A-S C= \\
\text { Fop } *\left(P_{E x}-P_{E n}\right)\end{array}$ & Equation (1) & $\begin{array}{l}\text { Fop-flow open path }(\mathrm{kg} / \mathrm{h}) \\
P_{E X} \text {-final product selling } \\
\text { price } \\
P_{E N} \text { - price of raw material }\end{array}$ \\
\hline $\begin{array}{l}\text { Energy } \\
\text { Cost-SC } \\
\text { (EC-SC) }\end{array}$ & $\begin{array}{l}\text { EC-SC provides the value of energy } \\
\text { consumption in a certain path. AF specifies } \\
\text { the allocation of the energy consumed per } \\
\text { path, estimated in mass or volume according } \\
\text { to Equations (3) and (4). } \\
\text { As expected, having high values of EC-SC } \\
\text { indicates the need for changes/improvements. }\end{array}$ & $\begin{array}{l}\text { Adapted } \\
\text { from [36] } \\
\text { to the } \\
\text { supply } \\
\text { chain } \\
\text { context }\end{array}$ & $\begin{array}{c}E C-S C= \\
\sum_{e=0}^{E} P_{U t} \times E n_{e} \times A F_{e} \\
A F=\frac{M F}{\sum_{p}^{P} M F} \\
A F=\frac{V F}{\sum_{p}^{P} V F}\end{array}$ & $\begin{array}{l}\text { Equation (2) } \\
\text { Equation (3) } \\
\text { Equation (4) }\end{array}$ & $\begin{array}{l}e \text {-entity } \\
P_{u t} \text {-price of utility } \\
E n_{e} \text { - energy consumed in } \\
\text { each entity of the path } \\
A F_{e} \text { - allocation factor of } \\
\text { the energy consumed } \\
M F \text {-mass flow } \\
V F \text { - volume flow }\end{array}$ \\
\hline
\end{tabular}

Inventory is needed to buffer market and operational uncertainties; however, it often hides inefficient management of supply chain processes. This potentially leads to damages to the supply chain competitiveness due to Total unnecessary and avoidable costs [44]. The Inventory inventory cost represents $33 \%$ of the logistics Level Cost cost [45]. To keep track of this, the Total (TILC) Inventory Level Factor (TILC) indicator provides information about the most critical paths with regard to inventory costs. When keeping more inventory than necessary, the TILC will present high values, which points out excess costs in this regard.

\begin{tabular}{|c|c|c|c|}
\hline $\begin{array}{l}\text { Developed } \\
\text { in this } \\
\text { work }\end{array}$ & $\begin{array}{c}I L C=\sum_{e=0}^{E} I n v_{e} * \\
H C_{e} * \text { Afe }\end{array}$ & Equation (5) & $\begin{array}{l}\operatorname{Inv}_{e} \text {-inventory of entity } e \\
H C_{e} \text { - holding cost of a } \\
\text { given SKU and entity } e\end{array}$ \\
\hline
\end{tabular}

EILC specifies which entity (or entities) is (are)

\begin{tabular}{|c|c|c|c|c|c|}
\hline $\begin{array}{l}\text { Entity } \\
\text { Inventory } \\
\text { Level Cost } \\
\text { (EILC) }\end{array}$ & $\begin{array}{l}\text { EILC specifies which entity (or entities) is (are) } \\
\text { the most critical in inventory cost, within the } \\
\text { identified critical path identified previously by } \\
\text { TILC. The closer to } 1 \text {, the worst the entity } \\
\text { performs in terms of inventory costs. }\end{array}$ & $\begin{array}{l}\text { Developed } \\
\text { in this } \\
\text { work }\end{array}$ & $\frac{E I L C=}{E I L v_{e} \times H C_{e} * A f e}=$ & Equation (6) & $\begin{array}{l}\text { (see nomenclature given in } \\
\text { indicator TILC) }\end{array}$ \\
\hline
\end{tabular}

Running out of stock potentially leads to the company losing the order. Furthermore, a poor service level might lead the customers to change to a competing company [46]. Hence, Backorder monitoring these losses is critical, and this can Cost (BC) be achieved by using the $\mathrm{BC}$ indicator, which displays the total value of lost sales in a given path. The price of the product suffers an increment due to client compensation. High $\mathrm{BC}$ points out inefficiencies.

$\begin{array}{ccll}\begin{array}{c}\text { Developed } \\ \text { in this }\end{array} & B C= & & \begin{array}{l}C \text {-demand of component } c \\ \text { wem }\end{array} \\ \text { work } & \left((1+i) \times F_{O P}\right) \times & \text { Equation }(7) & \begin{array}{l}\text { Dem }- \text { demand of } \\ \text { component } c\end{array}\end{array}$

Time

The flow of a product usually entails the loss of considerable time going through operations without any value to the client. According to [12], the majority of value streams can be compressed to reduce or even eliminate avoidable processing time. To this end, this subsection proposes three indicators for the purpose of tracking time. The lead time is a pivotal factor in measuring a supply chain's performance since it directly impacts the inventory performance as well as the production forecast [47]. Short lead times provide a very significant competitive advantage. Shortening the lead time might enable the value stream to respond to real orders, rather than inaccurate forecasts, and reduce waste [12].

Furthermore, the lead time also plays a significant role in the bullwhip effect; a long lead time in replenishment orders intensifies information distortion [48]. Moreover, inventory turnover is a standard metric used to show the number of times that the inventory is consumed in a period. It can be improved by applying economies of scale as local 
optimization. However, this can lead to the bullwhip effect [48]. To this end, this section proposes a group of indicators to efficiently assess time (see Table 4).

Table 4. Economic indicators: time.

\begin{tabular}{|c|c|c|c|c|c|}
\hline Indicator & Description & Reference & \multicolumn{2}{|c|}{ Equation } & Nomenclature \\
\hline $\begin{array}{l}\text { Lead Time } \\
\text { Factor (LTF) }\end{array}$ & $\begin{array}{l}\text { LTF gives the total lead } \\
\text { time of each path. It aims } \\
\text { at identifying the critical } \\
\text { paths with regard to lead } \\
\text { time, which can more } \\
\text { easily contribute to a } \\
\text { service level problem. } \\
\text { High values indicate the } \\
\text { need for improvements. }\end{array}$ & $\begin{array}{l}\text { Adapted from [37] } \\
\text { to the supply chain } \\
\text { context }\end{array}$ & $L T F=\sum_{e}^{E} L T_{e}$ & Equation (8) & $\begin{array}{l}L T \text {-lead time of } \\
\text { entity } e\end{array}$ \\
\hline $\begin{array}{l}\text { Operational } \\
\text { Lead Time } \\
\text { Factor (OLTF) }\end{array}$ & $\begin{array}{l}\text { OLTF identifies the most } \\
\text { critical entity (or entities) } \\
\text { within the critical paths } \\
\text { pointed out by LTF. High } \\
\text { values indicate potential } \\
\text { bottlenecks with regard to } \\
\text { the entity's lead time. }\end{array}$ & $\begin{array}{l}\text { Adapted from [37] } \\
\text { to the supply chain } \\
\text { context }\end{array}$ & $O L T F=\frac{L T_{e}}{\sum_{e}^{E} L T_{e}}$ & Equation (9) & $\begin{array}{c}\text { (see nomenclature } \\
\text { given in indicator LTF) }\end{array}$ \\
\hline $\begin{array}{c}\text { Inventory } \\
\text { Turnover (IT) }\end{array}$ & $\begin{array}{l}\text { IT indicator is used to } \\
\text { indicate which inventory } \\
\text { takes the longest to empty } \\
\text { in a given path. It is only } \\
\text { applied to entities with an } \\
\text { inventory. High values of } \\
\text { IT indicate high lead time, } \\
\text { which points to lower } \\
\text { agility of the path, and the } \\
\text { more noticeable the } \\
\text { bullwhip effect. }\end{array}$ & $\begin{array}{l}\text { Adapted from [12] } \\
\text { to the supply chain } \\
\text { context }\end{array}$ & $I T=\max \left(\frac{I n v_{e}}{\operatorname{Dem}_{e}}\right)$ & Equation (10) & $\begin{array}{c}D e m_{e} \text { - demand of } \\
\text { the downstream } \\
\text { process in } \\
\text { considered time } \\
\text { period } \\
\text { Inv } v_{e} \text {-largest } \\
\text { inventory of entity } e\end{array}$ \\
\hline
\end{tabular}

Quality

Measuring quality reflects the capacity of delivering high customer service [40], which means: (i) delivery of minimal defected products; (ii) in the demanded quantity; and (iii) in time [49]. A positive view on the company's service quality can lead to its long-term survival, while failure to achieve this might seriously damage its viability [50]. Furthermore, many supply chain models assume perfect systems, but, in any production system, there are flaws in the production processes as a result of human error and other causes [51]. Therefore, it is also essential to measure the performance of the production equipment. Buchmeister et al. (2012) [52] pointed out that the Overall Equipment Efficiency level $(O E E)$ of downstream stages has an important influence on inventory oscillation and order variability. Muthian and Huang (2007) [53] proposed the Overall Throughput Effectiveness $(O T E)$ metric to monitor performance at the factory level; this metric is based on OEE, which was firstly introduced by Nakajima (1988) [54]. Thus, to keep track of quality, this work proposes a set of metrics to assess all the relevant facets of quality in the supply chain (see Table 5). 
Table 5. Economic indicators: quality.

\begin{tabular}{|c|c|c|c|c|c|}
\hline Indicator & Description & Reference & Equation & & Nomenclature \\
\hline $\begin{array}{l}\text { Service } \\
\text { Level } \\
\text { Quantity } \\
\text { Factor } \\
\text { (SLQF) }\end{array}$ & $\begin{array}{l}\text { To keep track of the orders and } \\
\text { the product demand quantities, } \\
\text { SLQF informs if the orders are } \\
\text { being fully satisfied in terms of } \\
\text { the amount. When different } \\
\text { from } 0 \text {, it reports that the service } \\
\text { level in terms of quantity is not } \\
\text { at its best-that path is not } \\
\text { satisfying the customer and } \\
\text { thus needs to be improved. }\end{array}$ & $\begin{array}{l}\text { Developed in } \\
\text { this work }\end{array}$ & $S L Q F=\frac{D e m_{c}-F o p}{D e m_{c}}$ & Equation (11) & $\begin{array}{l}\text { (see nomenclature } \\
\text { given in indicators } \\
B C \text { and } M V A-S C \text { ) }\end{array}$ \\
\hline $\begin{array}{l}\text { Service } \\
\text { Level Time } \\
\text { Factor } \\
\text { (SLTF) }\end{array}$ & $\begin{array}{l}\text { Like SLQF, the SLTF indicator } \\
\text { informs about the time as a } \\
\text { service level by comparing the } \\
\text { actual product delivery time to } \\
\text { the expected/planned delivery } \\
\text { time specified in the order. } \\
\text { Values different from } 0 \text { indicate } \\
\text { that the path's service level in } \\
\text { terms of timely delivery needs } \\
\text { improvement. }\end{array}$ & $\begin{array}{l}\text { Developed in } \\
\text { this work }\end{array}$ & $S L T F=\frac{F_{O P-O n T i m e}}{F_{O P}}$ & Equation (12) & $\begin{array}{l}\text { OnTime-flowrate } \\
\text { of the open path } \\
\text { delivered according } \\
\text { to the scheduled time } \\
\text { (see nomenclature } \\
\text { given in indicator } \\
\text { MVA-SC) }\end{array}$ \\
\hline $\begin{array}{l}\text { OK-Parts } \\
\quad(\mathrm{OP})\end{array}$ & $\begin{array}{l}O P \text { keeps track and raises } \\
\text { awareness of the defected } \\
\text { products in the value stream. It } \\
\text { gives the ratio of product flow } \\
\text { that successfully reaches the } \\
\text { costumers with a suitable } \\
\text { quality compared to the total } \\
\text { amount produced. The lower } \\
\text { the } O P \text { value, the worse the } \\
\text { quality performance of the path. }\end{array}$ & $\begin{array}{l}\text { Developed in } \\
\text { this work }\end{array}$ & $\prod_{\mathcal{e}=0}^{E}\left(\begin{array}{c}O P= \\
100\end{array}\right.$ & Equation (13) & $\begin{array}{l}D e f_{e} \text {-defective } \\
\text { flowrate of entity e } \\
\text { (see nomenclature } \\
\text { given in indicators } \\
\text { EC-SC and } \\
M V A-S C \text { ) }\end{array}$ \\
\hline $\begin{array}{l}\text { Overall } \\
\text { Through- } \\
\text { put } \\
\text { Effective- } \\
\text { ness } \\
\text { (OTE-SC) }\end{array}$ & $\begin{array}{l}\text { To go a step further, in this } \\
\text { work, we propose the OTE-SC } \\
\text { metric to compare actual } \\
\text { productivity to the maximum } \\
\text { achievable productivity for a } \\
\text { given path. Low values of } \\
\text { OTE-SC indicate low } \\
\text { production performance and } \\
\text { the need to improve the } \\
\text { production yield. }\end{array}$ & $\begin{array}{l}\text { Adapted } \\
\text { from [53] to } \\
\text { the supply } \\
\text { chain context }\end{array}$ & $\begin{array}{c}O T E-S C= \\
\text { Fop } * 100\end{array}$ & Equation (14) & $\begin{array}{l}\text { TFop-theoretical } \\
\text { flow of an open } \\
\text { path working at } \\
\text { full yield } \\
\text { (see nomenclature } \\
\text { given in indicators } \\
\text { EC-SC and } \\
M V A-S C \text { ) }\end{array}$ \\
\hline
\end{tabular}

Flexibility

Flexibility is the aptitude to respond to quick changes in supply or demand [40]. Beamon (1999) [39] stated that supply chains' flexibility should be evaluated with regard to four aspects: volume, delivery, mix and new product. Nevertheless, these aspects are not always a concern for all supply chains since they are product-dependent. Furthermore, [55] singled out time and volume flexibility as a common source of disagreement among buyers and suppliers. Hence, this work covers volume flexibility and time flexibility. Volume flexibility is needed to overcome customer order oscillations, and time flexibility is critical to fulfilling rush or special orders [39] (see Table 6). 
Table 6. Economic indicators: flexibility.

\begin{tabular}{|c|c|c|c|c|c|}
\hline Indicator & Description & Reference & \multicolumn{2}{|c|}{ Equation } & Nomenclature \\
\hline $\begin{array}{l}\text { Flexibility } \\
\text { Volume Factor } \\
\text { (FVF) }\end{array}$ & $\begin{array}{l}F V F \text { assesses if the company } \\
\text { can adapt its production to } \\
\text { demand variation in terms of } \\
\text { quantity. Low values of } F V F \\
\text { indicate a low capacity to } \\
\text { adjust production to demand } \\
\text { variations. }\end{array}$ & $\begin{array}{l}\text { Developed in } \\
\text { this work }\end{array}$ & $\begin{array}{c}F V F= \\
\min \left(\frac{\mathrm{Cap}_{e}-\mathrm{Dem}_{e}}{\mathrm{Cap}_{e}}\right)\end{array}$ & Equation (15) & $\begin{array}{l}\text { Cap } \text { _ }_{\text {- process }} \\
\text { capacity of the entity } \\
\text { e of a given path } \\
\text { (see nomenclature } \\
\text { given in indicator } \\
\text { IT) }\end{array}$ \\
\hline $\begin{array}{l}\text { Flexibility Time } \\
\text { Factor (FTF) }\end{array}$ & $\begin{array}{l}F T F \text { quantifies the company's } \\
\text { capability to adapt production } \\
\text { to meet demand changes } \\
\text { regarding time. The lower the } \\
\text { value of } F T F, \text { the lower the } \\
\text { company's capacity to } \\
\text { respond to changes in } \\
\text { deadlines. }\end{array}$ & $\begin{array}{l}\text { Adapted from } \\
\text { [39] to the } \\
\text { supply chain } \\
\text { context }\end{array}$ & $\begin{array}{c}F T F= \\
\frac{(D D D-E D D)}{(D D D)}\end{array}$ & Equation (16) & $\begin{array}{l}\text { DDD-due date } \\
\text { for delivery } \\
\text { EDD-earliest due } \\
\text { date for which } \\
\text { delivery can be made } \\
\text { (see nomenclature } \\
\text { given in indicator } \\
\text { LTF) }\end{array}$ \\
\hline
\end{tabular}

\subsubsection{Step 3.2: Environmental Indicators}

Several quantitative performance metrics have been established to estimate the impact of the supply chain in the environment, such as GHG emissions, material recycling, waste production and energy use, among others [56]. In this work, the most critical environmental indicators identified in the literature [57] were collected and combined into the indicators presented in Table 7.

Table 7. Environmental indicators.

\begin{tabular}{|c|c|c|c|c|c|}
\hline Indicator & Description & Reference & \multicolumn{2}{|c|}{ Equation } & Nomenclature \\
\hline $\begin{array}{c}\text { Carbon } \\
\text { Emissions (CE) }\end{array}$ & $\begin{array}{l}C E \text { quantifies the } \mathrm{CO}_{2} \\
\text { emissions for each open path. } \\
\text { High values of } C E \text { indicate the } \\
\text { need to adopt more } \\
\text { energy-efficient equipment } \\
\text { and facilities and/or optimize } \\
\text { the supply chain operations. }\end{array}$ & $\begin{array}{l}\text { Developed in } \\
\text { this work }\end{array}$ & $\begin{array}{c}C E= \\
\sum_{e=0}^{E} A F_{e} \times C D E_{e}\end{array}$ & Equation (17) & $\begin{array}{l}C D E_{e}-\text { carbon } \\
\text { dioxide emissions } \\
\text { emitted by entity } e \\
\text { (see nomenclature } \\
\text { given in indicator } \\
\text { EC-SC) }\end{array}$ \\
\hline $\begin{array}{l}\text { Waste Factor } \\
\qquad(\mathrm{WF})\end{array}$ & $\begin{array}{l}W F \text { measures the material } \\
\text { waste disposal in the open } \\
\text { paths. High values of } W F \\
\text { point out a need for } \\
\text { improvements and potential } \\
\text { opportunities to reduce waste } \\
\text { of resources and reduce } \\
\text { operating costs by increasing } \\
\text { material recycling. }\end{array}$ & $\begin{array}{l}\text { Developed in } \\
\text { this work }\end{array}$ & $W F=\frac{\sum_{e=0}^{E} W_{e} * A F_{e}}{F o p}$ & Equation (18) & $\begin{array}{l}W_{e}-\text { material waste } \\
\text { from entity e } \\
\text { (see nomenclature } \\
\text { given in indicators } \\
M V A-S C \text { and EC-SC) }\end{array}$ \\
\hline $\begin{array}{l}\text { Sustainable } \\
\text { Energy (SE) }\end{array}$ & $\begin{array}{l}\text { To motivate companies to } \\
\text { commit to using more } \\
\text { sustainable energy sources, SE } \\
\text { measures the ratio of } \\
\text { sustainable energy on the } \\
\text { total energy consumed in the } \\
\text { supply chain operations. The } \\
\text { lower the ratio, the higher the } \\
\text { need to adopt more } \\
\text { environmentally friendly } \\
\text { sources of energy. }\end{array}$ & $\begin{array}{l}\text { Adapted from } \\
\text { [58] to the } \\
\text { supply chain } \\
\text { context }\end{array}$ & $\begin{array}{c}S E= \\
\frac{\sum_{e=0}^{E} G e n_{e} * A f_{e}}{\sum_{e=0}^{E} E n_{e} * A f_{e}} * 100\end{array}$ & Equation (19) & $\begin{array}{l}\text { Gen } n_{e} \text { - consumption } \\
\text { of green energy by } \\
\text { entity } e \\
\text { En } n_{e} \text {-consumption } \\
\text { of energy by entity } e \\
\text { (see nomenclature } \\
\text { given in indicator } \\
\text { EC-SC) }\end{array}$ \\
\hline
\end{tabular}


Table 8. Social indicators.

\begin{tabular}{|c|c|c|c|c|c|}
\hline Indicator & Description & Reference & \multicolumn{2}{|c|}{ Equation } & Nomenclature \\
\hline $\begin{array}{l}\text { Labor Equity } \\
\text { (LE) }\end{array}$ & $\begin{array}{l}\text { To assess the labor market, } L E \\
\text { describes the distribution of } \\
\text { employee compensation. The } \\
\text { closer the } L E \text { ratio is to one, the } \\
\text { better the distribution of equity. }\end{array}$ & $\begin{array}{l}\text { Adapted from } \\
\text { [60] to the } \\
\text { supply chain } \\
\text { context }\end{array}$ & $L E=\min \left(\frac{L s_{e}}{H s_{e}}\right)$ & Equation (20) & $\begin{array}{l}L S_{e} \text {-lowest salary } \\
\text { of a given entity } e \\
H S_{e} \text { - highest } \\
\text { salary of a given } \\
\text { entity } e \text { including } \\
\text { all benefits }\end{array}$ \\
\hline $\begin{array}{l}\text { Fatal Accident } \\
\text { Rate (FAR) }\end{array}$ & $\begin{array}{l}\text { FAR is a statistical method that } \\
\text { reports the number of fatal } \\
\text { incidents [61] of an activity } \\
\text { based upon the total number of } \\
\text { employees working their entire } \\
\text { lifetime. The higher the FAR, } \\
\text { the bigger the need to improve } \\
\text { procedures and/or change the } \\
\text { operations. FAR was firstly } \\
\text { proposed by the British } \\
\text { chemical industry and here } \\
\text { adjusted to the supply chain } \\
\text { context. }\end{array}$ & $\begin{array}{l}\text { Adapted from } \\
\text { [61] to the } \\
\text { supply chain } \\
\text { context }\end{array}$ & $\begin{array}{c}F A R= \\
\frac{\sum_{e=0}^{E} N i n c_{e} * 10^{8}}{\sum_{e=0}^{E} N E_{e} * W h_{e}}\end{array}$ & Equation (21) & $\begin{array}{l}N_{i n c_{e}} \text {-number of } \\
\text { incidents in entity } e \\
N E_{e} \text { - number of } \\
\text { employees that } \\
\text { work in entity } e \\
\text { Whe - working } \\
\text { hours per year in } \\
\text { entity } e\end{array}$ \\
\hline Corruption (C) & $\begin{array}{l}C \text { is an attempt to quantify the } \\
\text { effect of corruption on the social } \\
\text { sustainability of an enterprise. } \\
\text { The higher the } C \text {, the greater the } \\
\text { need to change policies to fight } \\
\text { corruption [59]. }\end{array}$ & $\begin{array}{l}\text { Developed in } \\
\text { this work }\end{array}$ & $C=\sum_{e=0}^{E} N l_{s_{e}}$ & Equation (22) & $\begin{array}{l}\mathrm{Nls}_{e} \text {-number of } \\
\text { lawsuits in entity } e\end{array}$ \\
\hline
\end{tabular}

\subsubsection{Step 3.3: Social Indicators}

Metrics of the social performance show the company's policies towards its stakeholders (e.g., suppliers, employees). These indicators provide information about its employment situation and its relationship with private and public institutions or community groups [37]. However, there is still a lack of agreement in the literature regarding the best approach to evaluate social sustainability [59]. Nonetheless, the authors of [59] identified four elements that stakeholders find worthy of protection: (i) labor practices, (ii) human rights, (iii) product responsibility and (iv) society. The indicators proposed in this work cover all the topics mentioned above and are defined in Table 8.

\subsubsection{Step 3.4: Information Indicators}

Information indicators aim to represent a new sustainability angle to assess the effectiveness of coordination among the supply chain members and the potential benefits of implementing information-sharing policies. The performance of the supply chain highly depends on the quality of the information. The information flows directly impact the inventory levels, shipments and the production schedules [48]. Furthermore, information distortion can lead to the presence of the bullwhip effect. Lee et al. (2004) [48] referred to the bullwhip effect as "the phenomenon where orders to the supplier tend to have a larger variance than sales to the buyer (i.e., demand distortion), and the distortion propagates upstream in an amplified form (i.e., variance amplification)".

Sabato and Bruccoleri (2005) [62] showed that reducing lead time variability is, in some cases, more effective in removing the bullwhip effect than lowering the average lead time. 
Table 9. Information indicators.

\begin{tabular}{|c|c|c|c|c|c|}
\hline Indicator & Description & Reference & \multicolumn{2}{|c|}{ Equation } & Nomenclature \\
\hline $\begin{array}{l}\text { Variability of } \\
\text { Lead Time } \\
\text { (VLT) }\end{array}$ & $\begin{array}{l}V L T \text { aims at monitoring the lead } \\
\text { time variability. High values } \\
\text { indicate the need to improve the } \\
\text { information flow's stability } \\
\text { across a given path within the } \\
\text { supply chain. }\end{array}$ & $\begin{array}{l}\text { Developed in } \\
\text { this work }\end{array}$ & $V L T=\frac{\sigma_{L T F}}{L T F}$ & Equation (23) & $\begin{array}{l}\sigma_{L T F} \text {-standard deviation } \\
\text { of the lead time factor of a } \\
\text { given path } \\
\text { LTF-lead time factor of a } \\
\text { given path }\end{array}$ \\
\hline $\begin{array}{l}\text { Bullwhip } \\
\text { Effect (BE) }\end{array}$ & $\begin{array}{l}B E \text { gives information } \\
\text { concerning the demand } \\
\text { variation in the more upstream } \\
\text { process of a certain path to } \\
\text { promote information sharing } \\
\text { and prevent the bullwhip effect. } \\
\text { The original equation used to } \\
\text { quantify the bullwhip } \\
\text { magnitude has been adapted to } \\
\text { fit with the open path context. } \\
\text { Since the more considerable } \\
\text { order quantity variations are } \\
\text { located in the most upstream } \\
\text { process [ } 48 \text { ], each path only } \\
\text { focuses on the demand increase } \\
\text { of the first entity considered in } \\
\text { the analysis. }\end{array}$ & $\begin{array}{l}\text { Adapted from } \\
\text { [63] to the open } \\
\text { path context }\end{array}$ & $B E=\frac{\sigma_{F o p}}{\sigma_{D e m}}$ & Equation (24) & $\begin{array}{l}\sigma_{F o p}-\text { variance of the } \\
\text { orders of the first entity of } \\
\text { a given path } \\
\sigma_{\text {Dem }} \text { - demand of flow of } \\
\text { a given path }\end{array}$ \\
\hline
\end{tabular}

The proposed indicators aim to prevent the bullwhip effect and ensure coordination among the supply chain members to reduce the variability of the lead time. These indicators are described in Table 9.

\subsection{Step 4: Bottleneck Identification and Potential Solutions}

The indicators defined above are applied to each path, and based on their values, the managers can potentially identify the most critical areas of the supply chain. In Table 10, a few guidelines and recommendations are suggested to improve each indicator separately and improve the supply chain's overall sustainability.

Table 10. Recommendations to improve each indicator estimated through the SustainSC-VSM methodology.

\begin{tabular}{|c|c|}
\hline Indicator & Recommendations \\
\hline MVA-SC & Redesign the production process, for example, by applying process intensification and/or process integration. \\
\hline EC-SC & Invest in equipment and vehicles that are more efficient, as well as investing in continuous heat integration. \\
\hline $\begin{array}{l}\text { TILC } \\
\text { EILC }\end{array}$ & $\begin{array}{l}\text { Decrease the level of production and demand uncertainty. The production uncertainty can be reduced by } \\
\text { implementing more robust production processes. Demand uncertainty can be decreased by identifying a significant } \\
\text { buffer near the end customer to protect the supply chain from market uncertainties or by applying a production } \\
\text { leveling technique ("heijuka"). }\end{array}$ \\
\hline$B C$ & Improve supply chain coordination and inventory management policies. \\
\hline $\begin{array}{l}\text { LTF } \\
\text { OLTF }\end{array}$ & $\begin{array}{l}\text { Ideally, all activities should be located at the same place near the end customer. This is often not possible, so the } \\
\text { recommendation is to find facilities that share material flows and locate them as close as possible. Using "just in } \\
\text { time" methods such as pull systems or process synchronization also shortens the lead time. }\end{array}$ \\
\hline IT & $\begin{array}{l}\text { Reduce the inventory by gradually ensuring not compromising the service level or reducing the batches' size and } \\
\text { increasing the pick-up frequency. }\end{array}$ \\
\hline $\begin{array}{l}V F \\
T F\end{array}$ & $\begin{array}{l}\text { Redirect the flow of material to another path with a lower workload, or boost the work capacity acquiring newer } \\
\text { and more effective equipment. }\end{array}$ \\
\hline$O K-P$ & $\begin{array}{l}\text { Implement failure prevention techniques ("poka yoke") to reduce scrap and rework in every facility's production } \\
\text { processes. }\end{array}$ \\
\hline
\end{tabular}


Table 10. Cont.

\begin{tabular}{ll}
\hline Indicator & Recommendations \\
\hline $\begin{array}{l}\text { SLQF } \\
\text { SLTF }\end{array}$ & $\begin{array}{l}\text { Improve the information sharing between the supply chain members to know the capacity constraints and each } \\
\text { supplier's inventory management. According to the collected information, find out how to deliver the required } \\
\text { orders in the proper quantity and time. }\end{array}$ \\
\hline OTE-SC & $\begin{array}{l}\text { Implement kaizen workshops to decrease the production uncertainty (technical, organizational and quality losses, } \\
\text { and changeover times). }\end{array}$ \\
\hline$V L T$ & Homogenize all the processes of the value stream to gain stability and ensure consistent results over time. \\
\hline$B E$ & $\begin{array}{l}\text { Adopt a centralized multi-echelon inventory control system since it presents a superior performance over } \\
\text { independently operating site-based inventory. }\end{array}$ \\
\hline$C E$ & Implement more energy-efficient equipment, vehicles and facilities; and/or optimize the supply chain operations. \\
\hline$S E$ & Reengineer the production process to be more efficient and promote recycling policies. \\
\hline$L E$ & Improve energy efficiency and invest in renewable and sustainable energy sources. \\
\hline$F A R$ & Improve the lowest salary and/or reduce the highest salary-decrease salary disparity. \\
\hline$C$ & Improve labor conditions by implementing robust security policies and provide training to the employees. \\
\hline
\end{tabular}

Noteworthy is that, based on Step 4, it is then possible to follow the recommendations and overcome the identified bottlenecks, therefore leading the user to the future value stream map (Figure 1).

\section{Results}

To validate the SustainSC-VSM methodology, as presented in Figure 1, Section 2, a case study of the supply chain of a heat exchanger manufacturer is used (adapted from Persson (2011) [64]). The case study presented in Figure 2 was selected as a good representative supply chain since (i) it refers to a relatively large company in Denmark and Nordic countries with an international supply chain; (ii) it has a discrete flow, which shows the applicability of SustainSC-VSM to the manufacturing and services sectors; and (iii) the data collected are real and complete.

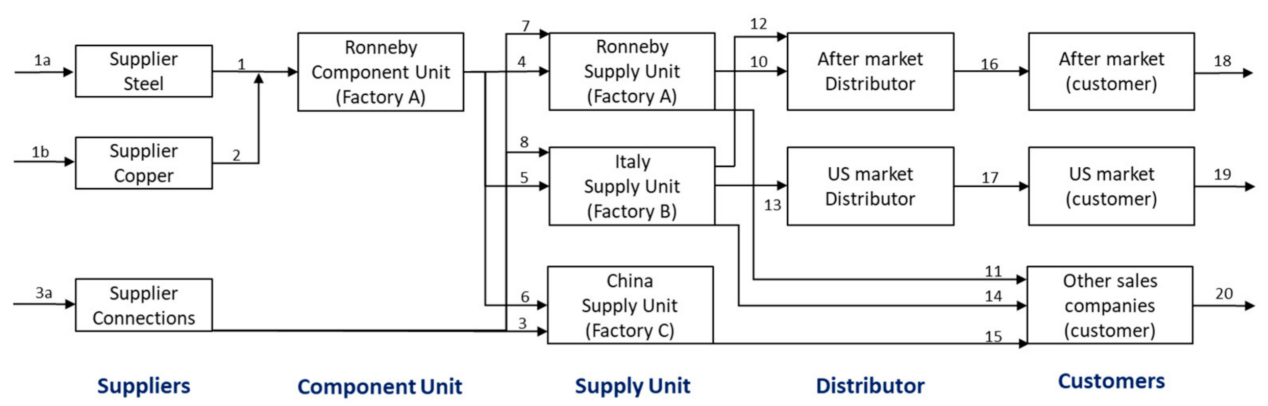

Figure 2. Case study of the supply chain of a heat exchangers manufacturer. Adapted from Persson (2011) [64].

Raw materials such as stainless steel, copper and other metals are obtained from different suppliers (1a, 2a and 3a, respectively) and transported to the main central manufacturing component unit in Ronneby, Factory A $(1,2)$. The critical components are subsequently distributed to the three supply units: Ronneby (4), Italy (5) and China (6). Connections are setup locally for each supply unit $(3,7,8)$. Distribution centers supply the U.S. (13) and the after-market $(10,12)$. The remaining companies and end customers are supplied by all supply units but not through the distribution centers $(11,14,15)$.

Streams 18, 19 and 20 represent the final products (heat exchangers) when they are sold to be implemented in the physical plant. 
A critical component used in the end product manufacture is produced in the component unit in Ronneby. Its production process is divided into two parts: one part that supplies the Ronneby supply unit in a make-to-order (MTO) environment, and the second part produces the component in a make-to-stock (MTS) environment (forecast-based). Moreover, the supply units (Ronneby S.U. and Italy S.U) are produced in an MTO environment. In this work, the case study is framed around the whole network. However, it only includes the "after-market" and the "U.S. market" as customers. Therefore, the flows were adapted to reflect this. Although this simplification somewhat changes the final results, it is sensible to accept the obtained results as valid, since the supply chain structure is already quite complex.

\subsection{Step 1: Extended Value Stream Map}

The supply chain structure presented in Figure 2 should be decomposed into three EVSMs since it has three known customers. However, due to space constraints, we will focus on the detailed representation and analysis of the after-market and the U.S. market EVSMs, as presented in Figures 3 and 4.

The Italian factory is located in Monza [65], and the distribution center is located in Denmark [66].

The required data to produce the EVSMs are summarized in Tables 11 and 12 and they were collected as follows:

- The distances between the different units were obtained by using Google Maps;

- The data needed for the complete description of the data boxes (EPEI, defects, inventory days, batch and demand) of the EVSM were collected from the Alfa Laval sustainability report [67];

- The demand was estimated based on the Alfa Laval sustainability report [67] and by applying some assumptions, such as: (i) the heat exchangers represent $40 \%$ of the sales in the equipment divisions, and (ii) the after-market represents $35 \%$ of the total market share.

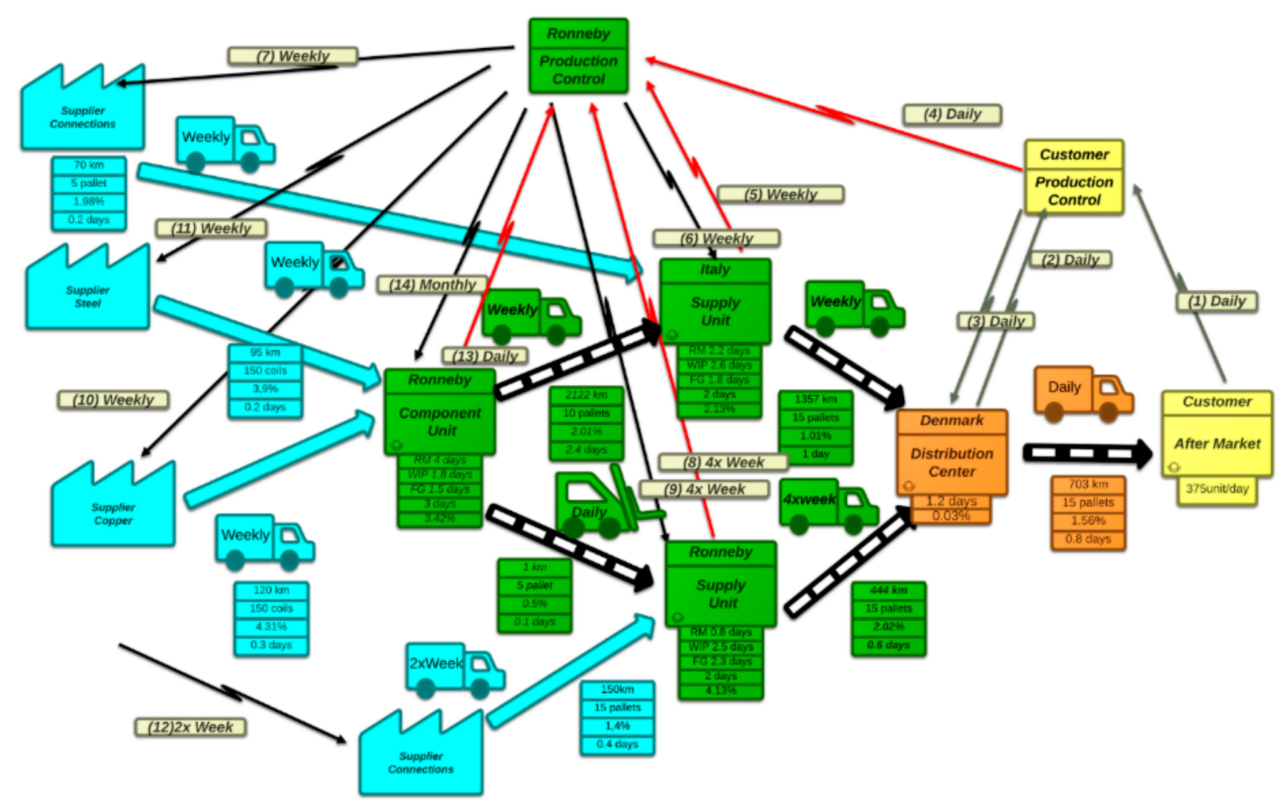

Figure 3. EVSM representation of the after-market developed in this work. Blue: supplier stage; green: manufacturing stages; orange: distributor stage; yellow: retailer stage. The EVSM was created in the Lucidchart software [68]. 
Table 11. Summary of the data regarding the entities.

\begin{tabular}{|c|c|c|c|c|c|c|c|c|}
\hline \multirow{2}{*}{ Data Boxes } & \multicolumn{4}{|c|}{ TIME } & \multirow{2}{*}{ Total } & \multirow{2}{*}{ EPEI } & \multirow{2}{*}{ Defects } & \multirow{2}{*}{ Steps } \\
\hline & Rm (Days) & WIP (Days) & FG (Days) & Value Added (s) & & & & \\
\hline Ronneby C.U. & 4 & 1.8 & 1.5 & 2346 & 7.3 & 3 days & $3.42 \%$ & $30(6)$ \\
\hline Ronneby S.U. & 0.8 & 2.5 & 2.3 & 1600 & 5.6 & 2 days & $4.13 \%$ & $26(5)$ \\
\hline Italy & 2.2 & 2.6 & 1.8 & 1789 & 6.6 & 2 days & $2.13 \%$ & $26(5)$ \\
\hline Distribution C. & & 1.2 & & 0 & 1.2 & & $0.03 \%$ & $4(0)$ \\
\hline
\end{tabular}

Table 12. Summary of the data regarding transportation.

\begin{tabular}{|c|c|c|c|c|c|c|}
\hline Transportation & Time & Distance (km) & Batch & Defects & Frequency & Steps \\
\hline Supplier Steel & 0.2 days & 95 & 150 coils & $3.90 \%$ & Weekly & 1 \\
\hline Supplier Copper & 0.3 days & 120 & 150 coils & $4.31 \%$ & Weekly & 1 \\
\hline Sup Connections IT & 02 days & 70 & 5 pallets $(75 \mathrm{u} / \mathrm{p})$ & $1.98 \%$ & Weekly & 1 \\
\hline Sup Connections RO & 0.4 days & 150 & 15 pallets $(50 \mathrm{u} / \mathrm{p})$ & $1.40 \%$ & $2 \times$ Week & 1 \\
\hline Ronneby C.O-IT & 2.4 days & 2122 & 10 pallets $(50 \mathrm{u} / \mathrm{p})$ & $2.01 \%$ & Weekly & 1 \\
\hline Ro C.U. -Ro S.U. & 0.1 days & 1 & 5 pallet $(50 \mathrm{u} / \mathrm{p})$ & $0.50 \%$ & Daily & 1 \\
\hline Ro S.U.- Distributor & 0.6 days & 444 & 15 pallets $(25 \mathrm{u} / \mathrm{p})$ & $2.02 \%$ & $4 \times$ Week & 1 \\
\hline Italy-Distributor & 1 day & 1357 & 15 pallets $(25 \mathrm{u} / \mathrm{p})$ & $1.01 \%$ & Weekly & 1 \\
\hline Distributor-Market & 0.8 days & 703 & 15 pallets $(25 \mathrm{u} / \mathrm{p})$ & $1.56 \%$ & Daily & 1 \\
\hline
\end{tabular}

The production control entities are the offices where the information flows are managed in the supply chain (all data are shared electronically between entities). As previously mentioned, the share of the component unit that serves Italy S.U. works in an MTS environment. The supply unit and the part of the component unit that serves Ronneby S.U. works in an MTO environment. Thus, the supply units only schedule batches in response to a confirmed order. Furthermore, the data reported in Table 13 were estimated in resemblance to the EVSM described in [12] and considering the supply chain description presented in [64]. The EVSM representation of the after-market was developed in this work, depicted in Figure 3. The nature and the frequency of the information flow are detailed in Table 13. Note that the information flows in Figure 3 are linked to the number presented in the first column.

Table 13. Description of the EVSM's information flow.

\begin{tabular}{cccc}
\hline Number & Information Flows & Frequency & Description Flow \\
\hline 1 & Costumer-PCCostumer & Daily & Consumption Information \\
\hline 2 & Distribution-PCCostumer & Daily & Shipping Release \\
\hline 3 & PCCostumer-Distribution & Daily & Orders \\
\hline 4 & PCCostumer-PCRonneby & Daily & Orders /Consumption Information \\
\hline 5 & Italy-PCRonneby & Weekly & Shipping Release \\
\hline 6 & PCRonneby-Italy & Weekly & Orders \\
\hline 7 & PCRonneby-Connections & $2 \times$ Week & Source Stocked Product \\
\hline 8 & Ronneby S.U.-PCRonneby & $4 \times$ Week & Shipping Release \\
\hline 10 & PCRonneby-Ronneby S.U. & $4 \times$ Week & Source Stocked Product \\
\hline 11 & PCRonneby-copper & Weekly & Source Stocked Product \\
\hline 12 & PCRonneby-steel & Weekly & Source Stocked Product \\
\hline 13 & PCRonneby-Connections & Weekly & Shipping Release \\
\hline 14 & Ronneby C.U.-PCRonneby & Daily & Forecast
\end{tabular}




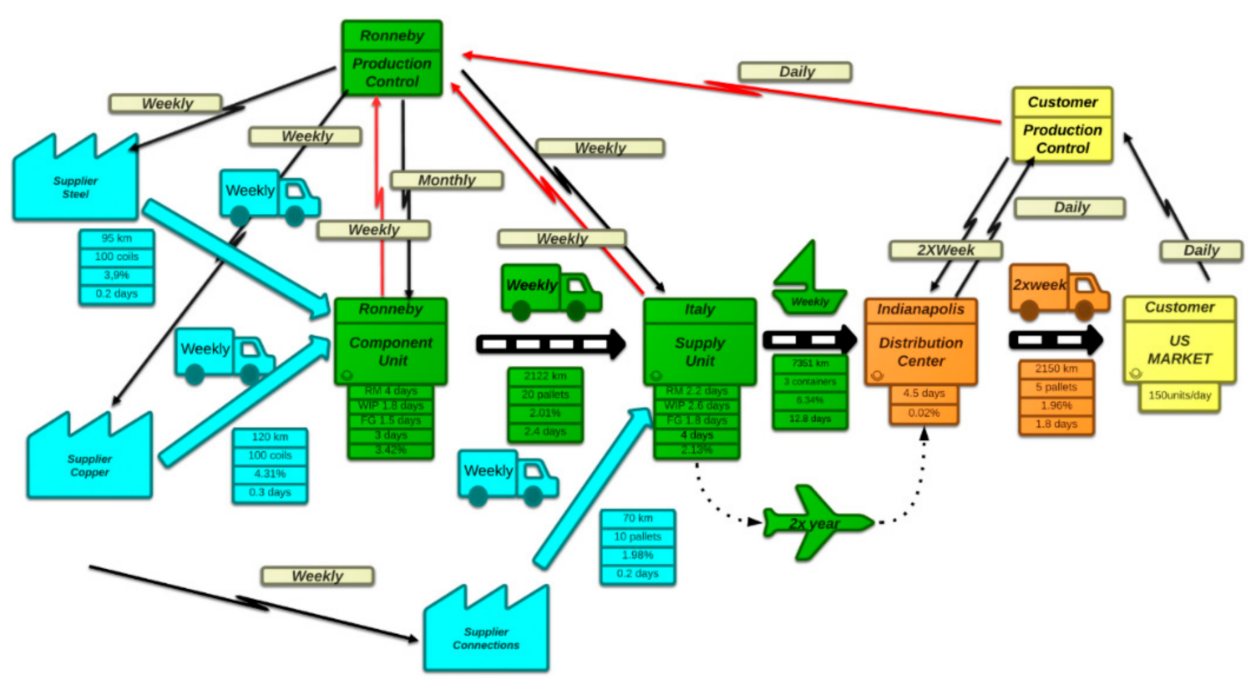

Figure 4. The EVSM of the U.S. customer market developed in this work. Blue: supplier stage; green: manufacturing stages; orange: distributor stage; yellow: retailer stage. The EVSM was created in the Lucidchart software [68].

The material flows of the EVSM presented in Figure 3 are described as follows:

i. The steel and copper suppliers send a weekly shipment of 150 coils to the Ronneby C.U.;

ii. The component unit is manufactured in the Ronneby C.U.;

iii. A fraction of the finished items are sent to the Italy S.U. by truck, and the others are sent to the Ronneby S.U. by milk run;

iv. The heat exchangers are manufactured in each supply unit. The heat exchangers are made of the component unit, which was sent earlier from the Ronneby C.U., and a connection component, which was acquired from a local supplier;

v. Once the heat exchangers are manufactured, the supply units' factories send the finished product to the distribution center in Denmark;

vi. The finished goods are distributed to all the retailers in the distribution center.

The information flows of the EVSM presented in Figure 3 are described as follows:

i. All retailers send daily information on the sales to the office of customer production control;

ii. All data are processed in the production control office, and the shipment orders are sent to the distribution center;

iii. The distribution center sends the shipments' confirmation back to the office of customer production control;

iv. The office of customer production control also sends the consumption data and the orders to the production control;

v. The information is then processed in Ronneby's production control office, and orders are sent to the supply units located in Ronneby and Italy;

vi. The Ronneby and Italy supply units send weekly and daily confirmation of the shipments, respectively;

vii. The Ronneby production control office also sends daily material requirements to the suppliers;

viii. The Ronneby production control office sends the monthly production forecast to the Ronneby C.U.

The EVSM of the U.S. customer market developed in this work is represented in Figure 4. The distribution center is located in Indianapolis, where Alfa Laval has a distribution center that supplies the U.S. market (https:/ / www.alfalaval.com/globalassets / images/misc/partnerdays/alfalavalpartnerdays2018-programme.pdf, accessed on 1 January 2021). 
The data presented in this step aim to depict the supply chain operations in a consistent and straightforward manner. The EVSM representation identified all the activities in accordance with their sequence and relationships.

Furthermore, as previously mentioned, the supply chain's structure and the production approach of each entity were obtained from Persson (2011) [64] and Alfa Laval's sustainability report [67]. However, in the sustainability report, the given figures include all company operations, mostly not relevant to this work. Thus, some assumptions were needed to be made to collect the required data.

The total inventory, lead time, demand, defective flow and inventory required for the EVSM are presented in Tables 12 and 13. Tables 14 and 15 summarize the details for each entity and transport flows. The sources of information used are detailed in Appendix B, Section 3. A summary of the data regarding the open paths is shown in Table 16.

Table 14. Data of entities and the respective transportation flows.

\begin{tabular}{|c|c|c|c|c|c|}
\hline Factories/Warehouse & Ronneby C.U. & Italy & Ronneby S.U. & Danish Distributor & EEUU Distributor \\
\hline $\begin{array}{l}\text { Price Utility } \\
\text { (EUR/MWh) }\end{array}$ & 80.00 & 170.00 & 80.00 & 100.00 & 61.90 \\
\hline $\begin{array}{l}\text { Energy Consumption } \\
\text { (MWh/year) }\end{array}$ & 6550 & 4100 & 4750 & 1000 & 800 \\
\hline Inventory Total (units) & 3300 & 1450 & 1850 & 450 & 675 \\
\hline $\begin{array}{l}\text { Holding Cost } \\
\text { (EUR/unit) }\end{array}$ & 9 & 11 & 12 & 22 & 20 \\
\hline Lead Time (days) & 7.3 & 6.6 & 5.6 & 1.2 & 4.5 \\
\hline Demand (units/day) & 375 & 225 & 300 & 375 & 150 \\
\hline $\begin{array}{l}\text { Defective Flow } \\
\text { (kg/year) }\end{array}$ & 9975.00 & 6508.33 & $25,697.78$ & 933.33 & 30.00 \\
\hline $\begin{array}{l}\text { Process Capacity } \\
\text { (units/day) }\end{array}$ & 400 & 250 & 305 & 500 & 300 \\
\hline $\begin{array}{l}\text { Carbon Footprint } \\
\text { (tones/year) }\end{array}$ & 5245 & 3875 & 3245 & 635 & 425 \\
\hline Waste (kg/year) & 23,000 & 13,500 & 28,750 & 933.33 & 30 \\
\hline $\begin{array}{l}\text { Green Energy } \\
\text { Consumption } \\
\text { (MWh/year) }\end{array}$ & 400 & 0 & 249 & 0 & 0 \\
\hline Number Incidents & 1 & 0 & 2 & 1 & 0 \\
\hline Employees (people) & 740 & 320 & 524 & 60 & 50 \\
\hline Number of Lawsuits & 1 & 0 & 1 & 0 & 0 \\
\hline $\begin{array}{l}\text { Largest Inventory } \\
\text { (units) }\end{array}$ & 1500 & 585 & 750 & 450 & 675 \\
\hline $\begin{array}{l}\text { Lowest Salary } \\
\text { (EUR/year) }\end{array}$ & 21,000 & 19,000 & 23,000 & 23,000 & 24,000 \\
\hline $\begin{array}{l}\text { Highest Salary } \\
\text { (EUR/year) }\end{array}$ & 68,000 & 66,000 & 70,000 & 85,000 & 76,000 \\
\hline Working Hours (year) & 1607 & 1752 & 1607 & 1411 & 1770 \\
\hline
\end{tabular}


Table 15. Data related to transport flows.

\begin{tabular}{|c|c|c|c|c|c|c|c|c|c|c|c|}
\hline Transport & Sup Steel & Sup Copper & Sup Con IT & Sup Con RO & Ro C.O-IT & $\begin{array}{l}\text { Ro C.U. -Ro } \\
\text { S.U. }\end{array}$ & $\begin{array}{c}\text { Ro S.U.- } \\
\text { Danish D.C. }\end{array}$ & $\begin{array}{l}\text { It-Danish } \\
\text { D.C. }\end{array}$ & $\begin{array}{l}\text { Danish D.C.- } \\
\text { After-Market }\end{array}$ & It-U.S. D.C & $\begin{array}{c}\text { U.S. D.C.-U.S } \\
\text { Market }\end{array}$ \\
\hline $\begin{array}{l}\text { Price Utility } \\
\text { (EUR/MWh) }\end{array}$ & 102 & 102 & 109.3 & 102 & 102 & 102 & 102 & 109.3 & 110 & 67 & 67 \\
\hline $\begin{array}{l}\text { Energy } \\
\text { Consumption } \\
\text { (MWh/year) }\end{array}$ & 12.4 & 15.7 & 9.1 & 39.2 & 276.9 & 0.7 & 231.8 & 177.1 & 458.7 & 959.3 & 561.5 \\
\hline $\begin{array}{l}\text { Lead Time } \\
\text { (days) }\end{array}$ & 0.2 & 0.3 & 0.2 & 0.4 & 2.4 & 0.1 & 0.6 & 1 & 0.8 & 12.8 & 1.8 \\
\hline $\begin{array}{l}\text { Defective Flow } \\
\text { (kg/year) }\end{array}$ & 8775 & 2873.3 & 264 & 1960 & 1172.5 & 1166.7 & 5027.6 & 628.4 & 4853.3 & 9510 & 2940 \\
\hline $\begin{array}{l}\text { Carbon } \\
\text { Footprint (ton } \\
\mathrm{CO}_{2} \text { /year) }\end{array}$ & 112.75 & 42.2 & 12.92 & 179.6 & 652.96 & 4.9 & 2331.7 & 445.4 & 5768.5 & 5816.4 & 3402.4 \\
\hline $\begin{array}{l}\text { Green Energy } \\
\text { (MWh/year) }\end{array}$ & 0 & 0 & 0 & 0 & 0 & 0 & 0 & 0 & 0 & 0 & 0 \\
\hline $\begin{array}{l}\text { Number of } \\
\text { Incidents }\end{array}$ & 0 & 1 & 0 & 0 & 1 & 1 & 1 & 0 & 1 & 0 & 0 \\
\hline $\begin{array}{l}\text { Employees } \\
\text { (people) }\end{array}$ & 1 & 1 & 1 & 1 & 1 & 1 & 1 & 1 & 2 & 3 & 2 \\
\hline $\begin{array}{l}\text { Number of } \\
\text { Lawsuits }\end{array}$ & 0 & 1 & 1 & 0 & 0 & 0 & 0 & 0 & 0 & 0 & 0 \\
\hline $\begin{array}{l}\text { Waste } \\
\text { (kg/year) }\end{array}$ & 8775 & 2873.3 & 264 & 1960 & 1172.5 & 1166.7 & 5027.6 & 628.4 & 4853.3 & 9510 & 2940 \\
\hline $\begin{array}{l}\text { Lowest Salary } \\
\text { (EUR/year) }\end{array}$ & 17,000 & 20,000 & 18,000 & 16,000 & 17,000 & 18,00 & 19,000 & 22,000 & 26,000 & 26,000 & 19,000 \\
\hline $\begin{array}{l}\text { Highest Salary } \\
\text { (EUR/year) }\end{array}$ & 50,000 & 56,000 & 56,000 & 45,000 & 36,000 & 44,000 & 50,000 & 55,000 & 84,000 & 75,000 & 66,000 \\
\hline $\begin{array}{l}\text { Working } \\
\text { Hours (year) }\end{array}$ & 1607 & 1607 & 1752 & 1607 & 1607 & 1607 & 1607 & 1752 & 1411 & 1770 & 1770 \\
\hline
\end{tabular}


Table 16. Data related to the open paths.

\begin{tabular}{|c|c|c|c|c|c|c|c|c|c|}
\hline Path & OP1 & OP 2 & OP3 & OP4 & OP5 & OP6 & OP7 & OP8 & OP9 \\
\hline $\begin{array}{l}\text { Price of Product } \\
\text { (EUR/kg) }\end{array}$ & 140 & 140 & 140 & 140 & 140 & 140 & 140 & 140 & 140 \\
\hline $\begin{array}{l}\text { Price of Raw } \\
\text { Material } \\
(\text { EUR } / \mathrm{kg})\end{array}$ & 2.1 & 2.1 & 5.68 & 5.68 & 3.50 & 2.6 & 140 & 140 & 140 \\
\hline $\begin{array}{l}\text { Customer } \\
\text { Demand } \\
\text { (kg/year) }\end{array}$ & 180,000 & 45,000 & 55,000 & 13,500 & 142,500 & 35,000 & 250,000 & 62,222 & 150,500 \\
\hline $\begin{array}{l}\text { On Time } \\
\text { (kg/year) }\end{array}$ & 180,000 & 45,000 & 50,000 & 10,000 & 125,000 & 34,000 & 230,000 & 61,000 & 146,000 \\
\hline $\begin{array}{l}\text { Theoretical Flow } \\
\text { (kg/year) }\end{array}$ & 210,000 & 52,000 & 61,500 & 15,500 & 160,000 & 37,500 & 275,000 & 67,500 & 170,000 \\
\hline $\begin{array}{l}\text { Due Date for } \\
\text { Delivery (days) }\end{array}$ & 15 & 18 & 15 & 19 & 6 & 9 & 9 & 11 & 28 \\
\hline $\begin{array}{l}\text { Earliest Due Date } \\
\text { (days) }\end{array}$ & 13 & 14 & 13 & 14 & 5.6 & 5 & 8 & 7 & 24 \\
\hline $\begin{array}{l}\text { The Variance of } \\
\text { Lead Time (days) }\end{array}$ & 2.2 & 2.6 & 1.2 & 1.5 & 2.2 & 0.8 & 2 & 2.2 & 4 \\
\hline $\begin{array}{l}\text { The Variance of } \\
\text { Demand }(\mathrm{kg} / \mathrm{y})\end{array}$ & 10,000 & 5000 & 4000 & 1000 & 6000 & 5000 & 50,000 & 10,000 & 7500 \\
\hline $\begin{array}{l}\text { The Variance of } \\
\text { Flow Path }(\mathrm{kg} / \mathrm{y})\end{array}$ & 10,500 & 5550 & 4800 & 1050 & 7000 & 5100 & 65,000 & 11,500 & 8800 \\
\hline Penalty Rate & 0.1 & 0.15 & 0.1 & 0.15 & 0.1 & 0.15 & 0.7 & 0.7 & 0.6 \\
\hline
\end{tabular}




\subsection{Step 2: Path Decomposition}

SustainPro [13] was used to generate the open paths for the two EVSMs previously mentioned. The reader is referred to Carvalho et al., 2008 [36,69] for details on SustainPro's inbuilt methodology used for path decomposition. Thus, network decomposition was applied, and a total of 15 open paths were obtained, representing the whole supply chain. However, since this study, as mentioned before, focuses solely on the paths related to the after-market and the U.S. customer market, only the corresponding open paths will be analyzed. This totals to nine out of the fifteen open paths identified, as presented in Table 17. The path decomposition for the nine open paths is presented in Table 17, where each path is linked to a component and a flow which forms the flow-path.

Table 17. Path decomposition of the EVSM representing the U.S. customer market.

\begin{tabular}{|c|c|c|c|}
\hline Open Path & Component & Flow $\left(\mathrm{kg} / \mathrm{y} \times 10^{3}\right)$ & Description \\
\hline 1 & Steel & 180 & $\begin{array}{l}\text { (Steel Supplier } \rightarrow \text { Ronneby C.U. } \\
\quad \rightarrow \text { Ronneby S.U.) }\end{array}$ \\
\hline 2 & Steel & 45 & $\begin{array}{c}\text { (Steel Supplier } \rightarrow \text { Ronneby C.U. } \\
\rightarrow \text { Italian S.U.) }\end{array}$ \\
\hline 3 & Copper & 53.3 & $\begin{array}{l}\text { (Copper Supplier } \rightarrow \text { Ronneby } \\
\text { C.U. } \rightarrow \text { Ronneby S.U.) }\end{array}$ \\
\hline 4 & Copper & 13.3 & $\begin{array}{c}\text { (Copper Supplier } \rightarrow \text { Ronneby } \\
\text { C.U. } \rightarrow \text { Italian S.U.) }\end{array}$ \\
\hline 5 & Connections & 140 & $\begin{array}{c}\text { (Connections Supplier } \rightarrow \\
\text { Ronneby S.U.) }\end{array}$ \\
\hline 6 & Connections & 35 & $\begin{array}{c}\text { (Connections Supplier } \rightarrow \text { Italian } \\
\text { S.U.) }\end{array}$ \\
\hline 7 & Heat Exchanger & 248.9 & $\begin{array}{c}\text { (Ronneby S.U. } \rightarrow \text { Danish } \\
\text { distribution center } \rightarrow \\
\text { after-market) }\end{array}$ \\
\hline 8 & Heat Exchanger & 62.2 & $\begin{array}{l}\text { (Italian S.U. } \rightarrow \text { Danish } \\
\text { distribution center } \rightarrow \\
\text { after-market) }\end{array}$ \\
\hline 9 & Heat Exchanger & 150 & $\begin{array}{c}\text { (Italian S.U. } \rightarrow \text { Indianapolis } \\
\text { distribution center } \rightarrow \\
\text { after-market) }\end{array}$ \\
\hline
\end{tabular}

\subsection{Step 3: Calculation of the Indicators}

In this section, the indicators included in the SustainSC-VSM methodology are estimated for all the open paths. As mentioned in the detailed description of the indicators presented in Section 2, Step 3.1, the indicators EILC (Entity Inventory Level Cost) and OLTF (Operational Lead Time Factor) characterize the supply chain's entities. Thus, Tables 18 and 19 summarize the indicators with regard to EILC and OLTF. In contrast, Table 20 summarizes the remaining indicators' values, which correspond to the U.S. market and the after-market open paths. As observed, the worst paths regarding the EILC and OLTF indicators are OP1 and OP9, respectively. The most critical open path with regard to inventory is OP1 (see Table 18); thereby, the EILC indicator is applied only to this path. In terms of the lead time, the most critical is OP9. 
Table 18. EILC indicator of open path 1 in the entities regarding inventory. Values highlighted in red represent the worst performance.

\begin{tabular}{cl}
\hline Open Path 1 & EILC \\
\hline Ronneby C.U. & 0.741 \\
\hline Ronneby S.U. & 0.259 \\
\hline
\end{tabular}

Table 19. OLTF for the critical open path 9 regarding entities concerning lead time. Values highlighted in red represent the worst performance.

\begin{tabular}{cc}
\hline Open Path 9 & OLTF \\
\hline Italian S.U. & 0.257 \\
\hline It S.U.-Indianapolis Distribution center & 0.498 \\
\hline Indianapolis Distribution center & 0.070 \\
\hline Indianapolis Distribution center -U.S. market & 0.175 \\
\hline
\end{tabular}

Table 20. Values of the indicators for all open paths. Values highlighted in red represent the worst performance.

\begin{tabular}{|c|c|c|c|c|c|c|c|c|c|c|}
\hline & & OP1 & OP2 & OP3 & OP4 & OP5 & OP6 & OP7 & OP8 & OP9 \\
\hline \multirow{4}{*}{ Economic } & $M V A$ & $\begin{array}{c}\text { EUR } \\
24,822,000\end{array}$ & $\begin{array}{c}\text { EUR } \\
6,205,500\end{array}$ & $\begin{array}{c}\text { EUR } \\
7,163,733\end{array}$ & $\begin{array}{c}\text { EUR } \\
1,790,933\end{array}$ & $\begin{array}{c}\text { EUR } \\
19,110,000\end{array}$ & $\begin{array}{c}\text { EUR } \\
4,809,000\end{array}$ & - EUR & - EUR & - EUR \\
\hline & $E C$ & $\begin{array}{c}\text { EUR } \\
434,374\end{array}$ & $\begin{array}{c}\text { EUR } \\
205.537\end{array}$ & $\begin{array}{c}\text { EUR } \\
129,682\end{array}$ & $\begin{array}{c}\text { EUR } \\
61,145\end{array}$ & $\begin{array}{c}\text { EUR } \\
89,493\end{array}$ & $\begin{array}{c}\text { EUR } \\
80,837\end{array}$ & $\begin{array}{c}\text { EUR } \\
296,007\end{array}$ & $\begin{array}{c}\text { EUR } \\
191,388\end{array}$ & $\begin{array}{c}\text { EUR } \\
493,554\end{array}$ \\
\hline & TILC & $\begin{array}{c}\text { EUR } \\
24,751\end{array}$ & $\begin{array}{l}\text { EUR } \\
6931\end{array}$ & $\begin{array}{l}\text { EUR } \\
7334\end{array}$ & $\begin{array}{l}\text { EUR } \\
2054\end{array}$ & $\begin{array}{l}\text { EUR } \\
4995\end{array}$ & $\begin{array}{l}\text { EUR } \\
1827\end{array}$ & $\begin{array}{c}\text { EUR } \\
16,800\end{array}$ & $\begin{array}{l}\text { EUR } \\
5228\end{array}$ & $\begin{array}{c}\text { EUR } \\
13,505\end{array}$ \\
\hline & $B$ & - EUR & - EUR & $\begin{array}{c}\text { EUR } \\
256,667\end{array}$ & $\begin{array}{c}\text { EUR } \\
26,833\end{array}$ & $\begin{array}{c}\text { EUR } \\
154,000\end{array}$ & - EUR & $\begin{array}{c}\text { EUR } \\
264,444\end{array}$ & - EUR & $\begin{array}{c}\text { EUR } \\
112,000\end{array}$ \\
\hline Time & LTF & 13.20 & 16.50 & 13.30 & 16.60 & 6.00 & 6.80 & 8.20 & 9.60 & 25.70 \\
\hline & IT & 4.00 & 4.00 & 4.00 & 4.00 & 2.50 & 2.60 & 2.50 & 2.60 & 4.50 \\
\hline \multirow{2}{*}{ Flexibility } & $V F$ & 0.02 & 0.06 & 0.02 & 0.06 & 0.02 & 0.10 & 0.02 & 0.10 & 0.10 \\
\hline & $T F$ & 0.13 & 0.22 & 0.13 & 0.26 & 0.07 & 0.44 & 0.11 & 0.36 & 0.14 \\
\hline \multirow{3}{*}{ Quality } & $S L Q F$ & 0.000 & 0.000 & 0.03 & 0.01 & 0.01 & 0.000 & 0.00 & 0.00 & 0.00 \\
\hline & SLTF & 0.000 & 0.000 & 0.06 & 0.25 & 0.11 & 0.03 & 0.08 & 0.02 & 0.03 \\
\hline & $O K-P$ & $88.5 \%$ & $89 \%$ & $88.2 \%$ & $88.6 \%$ & $94.5 \%$ & $97.1 \%$ & $92.2 \%$ & $95.1 \%$ & $90.8 \%$ \\
\hline & OTE & $85.7 \%$ & $86.5 \%$ & $86.7 \%$ & $86.0 \%$ & $87.5 \%$ & $93.3 \%$ & $90.5 \%$ & $92.2 \%$ & $88.2 \%$ \\
\hline \multirow{2}{*}{ Information } & $V L T$ & 0.17 & 0.16 & 0.09 & 0.09 & 0.37 & 0.12 & 0.24 & 0.23 & 0.16 \\
\hline & $B E$ & 1.05 & 1.11 & 1.20 & 1.05 & 1.17 & 1.02 & 1.30 & 1.15 & 1.17 \\
\hline \multirow{3}{*}{ Environment } & $C E$ & 4241.45 & 1748.29 & 1261.65 & 519.24 & 885.21 & 452.91 & 6668.55 & 2035.46 & 8780.47 \\
\hline & $W F$ & 0.17 & 0.18 & 0.17 & 0.19 & 0.06 & 0.05 & 0.09 & 0.07 & 0.22 \\
\hline & $S E$ & 0.06 & 0.03 & 0.06 & 0.03 & 0.05 & 0.00 & 0.03 & 0.00 & 0.00 \\
\hline \multirow{3}{*}{ Society } & $L E$ & 0.31 & 0.29 & 0.31 & 0.29 & 0.33 & 0.29 & 0.27 & 0.27 & 0.29 \\
\hline & C & 2 & 1 & 3 & 2 & 1 & 1 & 1 & 1 & 0 \\
\hline & $F A R$ & 197 & 114 & 246 & 171 & 237 & 0 & 537 & 308 & 0 \\
\hline
\end{tabular}

\subsection{Step 4: Bottleneck Identification and Potential Solutions}

In this section, the supply chain's bottlenecks are identified and analyzed. Moreover, some suggestions are provided to tackle these bottlenecks. The indicators are grouped in the same order as presented in the description of the methodology in Section 2. 


\subsubsection{Economic Indicators}

The economic indicators are analyzed in Table 21 to identify the potential creation of wealth for the customer and assess the organization's resource effectiveness in the supply chain. The higher the performance, the greater the level of competitiveness of the supply chain.

Table 21. Identification of bottlenecks based on the economic indicators, and suggestions to overcome these bottlenecks.

\begin{tabular}{|c|c|}
\hline $\begin{array}{l}\text { Material Value } \\
\text { Added (MVA-SC) }\end{array}$ & $\begin{array}{l}\text { The supply chain is working in the right conditions: no negative MVA-SC } \\
\text { values have been limited improvements. }\end{array}$ \\
\hline $\begin{array}{l}\text { Energy Cost } \\
\text { (EC-SC) }\end{array}$ & $\begin{array}{l}\text { OP9 seems to be the most critical path in terms of energy consumption } \\
\text { (heat exchangers' distribution from Italy to the USA market). It indicates } \\
\text { the possibility of opening or using an existing factory in the U.S. to } \\
\text { manufacture the components currently produced in Italy. This would also } \\
\text { entail a change in the raw materials' suppliers. Still, it would reduce the } \\
\text { transportation costs as the material to transfer will not be the final product, } \\
\text { but its components would reduce energy consumption. }\end{array}$ \\
\hline $\begin{array}{l}\text { Total Inventory } \\
\text { Level Cost (TILC) } \\
\text { and Entity } \\
\text { Inventory Level } \\
\text { Cost (EILC) }\end{array}$ & $\begin{array}{l}\text { OP1 is the most expensive path in terms of inventory. EILC indicates that } \\
\text { the Ronneby C.U. factory has the largest inventory cost in OP1. This is due } \\
\text { to the centralized production of component units, which gives the biggest } \\
\text { circulation of flow through the Ronneby C.U. entity. Thus, to avoid this } \\
\text { bottleneck, a change from the current MTS policy to MTO would be } \\
\text { appropriate to reduce unnecessary inventory. }\end{array}$ \\
\hline $\begin{array}{l}\text { Backorder Cost } \\
\text { (BC) }\end{array}$ & $\begin{array}{l}\text { OP7 is identified as being the most expensive in terms of losses for not } \\
\text { meeting the demand requests. This indicator's assessment should be a } \\
\text { priority since the most competitive market with lower customer loyalty is } \\
\text { the after-market (see the penalty rate in Table 15). Back-ordering can } \\
\text { jeopardize the economic feasibility of the supply chain. OP3 and OP5 are } \\
\text { pointed out as the second and third worst open paths with regard to } \\
\text { back-ordering. These results indicate the need for a detailed analysis of the } \\
\text { Ronneby S.U. entity, since OPs } 7,3 \text { and } 5 \text { have the Ronneby S.U. facility in } \\
\text { common. }\end{array}$ \\
\hline $\begin{array}{l}\text { Lead Time Factor } \\
\text { (LTF) and } \\
\text { Operational Lead } \\
\text { Time Factor (OLTF) }\end{array}$ & $\begin{array}{l}\text { OP9 is the most critical path in terms of LTF. This is associated with the } \\
\text { distribution of heat exchangers from Italy to the U.S. customer market. } \\
\text { Analyzing OP9's OLTF, it is clear that this is the path that carries the most } \\
\text { significant bottleneck concerning lead time (Table 20). According to the } \\
\text { EC-SC indicator, it would be beneficial to study the use of the facilities that } \\
\text { Alfa Laval has in the U.S. to produce the components that are being } \\
\text { produced in Italy (lower transportation time). }\end{array}$ \\
\hline Inventory Turn (IT) & $\begin{array}{l}\text { OP9 is the most severe in terms of inventory turns-the distribution center } \\
\text { appears to be the bottleneck. There is only one weekly shipment from Italy } \\
\text { to Indianapolis due to the great distance between these entities. Thus, each } \\
\text { order batch is large and takes a long while to be consumed. Adopting the } \\
\text { proposed solutions in the EC-SC and LTF indicators would allow for more } \\
\text { regular supplier shipments with a lower order batch, thereby reducing the } \\
\text { non-value-added time and improving economic performance. If not } \\
\text { possible to change the production location, implementing techniques such } \\
\text { as a pull system to link the downstream process's demand with the } \\
\text { production of the upstream process would also reduce inventory time. }\end{array}$ \\
\hline $\begin{array}{l}\text { Flexibility Volume } \\
\text { Factor (FVF) }\end{array}$ & $\begin{array}{l}\text { OPs } 1,3,5 \text { and } 7 \text { have the lowest volume flexibility of the supply chain. } \\
\text { These paths share the Ronneby S.U. factory, which seems to be the } \\
\text { bottleneck. This bottleneck indicates a very tight production schedule, } \\
\text { which translates into losses due to back-ordering (Table } 20 \text { and } B C \\
\text { analysis). To tackle this, balancing the supply unit factories' workload } \\
\text { seems to be the best option: (i) transfer a share of the production volume to } \\
\text { the Italian supply unit factory, or (ii) invest in new equipment to increase } \\
\text { effectiveness of the Ronneby S.U. }\end{array}$ \\
\hline
\end{tabular}


Table 21. Cont.

\begin{tabular}{|c|c|}
\hline $\begin{array}{l}\text { Flexibility Time } \\
\text { Factor (FTF) }\end{array}$ & $\begin{array}{l}\text { OP5, followed by OP7, OP1 and OP3, is the most critical path in terms of } \\
\text { time flexibility. This is closely related to the very limited volume flexibility } \\
\text { of the Ronneby S.U. Thus, the measures stated above (analysis of BC and } \\
F V F \text { ) should be implemented to solve this threat to the supply chain's } \\
\text { overall sustainability. }\end{array}$ \\
\hline $\begin{array}{l}\text { Service Level } \\
\text { Quantity Factor } \\
\text { (SLQF) and Service } \\
\text { Level Time Factor } \\
\text { (SLTF) }\end{array}$ & $\begin{array}{l}\text { OP3 has the worst delivery performance in terms of the quantity. OP4 is } \\
\text { the most critical path in terms of time service level and the second worst in } \\
\text { quantity service level. Both OP3 and OP4 share the same copper supplier } \\
\text { (see EVSM, Figure 3). This is the source of the low service level, which } \\
\text { indicates that it would be beneficial to look for new suppliers to ensure a } \\
\text { steady flow of raw material. }\end{array}$ \\
\hline Ok-Parts (OP) & $\begin{array}{l}\text { OP3, followed by OP1, OP2 and OP4, is the most critical path in } \\
\text { manufacturing quality (see Table 20). All these paths flow through the } \\
\text { Ronneby C.U. factory and are the upstream paths in the supply chain (see } \\
\text { EVSM, Figure 3). The most upstream entities should launch a kaizen project } \\
\text { to implement the jidoka and poka yoke (mistake-proofing processes) } \\
\text { approaches to reduce the scrap and the rework. }\end{array}$ \\
\hline $\begin{array}{l}\text { Overall } \\
\text { Throughput } \\
\text { Effectiveness } \\
\text { (OTE-SC) }\end{array}$ & $\begin{array}{l}\text { OP1 has the lowest overall throughput effectiveness in the supply chain, } \\
\text { which is probably caused by quality losses. Still, a more in-depth study } \\
\text { should be led to assess the technical losses (machinery breakdowns) and } \\
\text { organizational losses (lack of resources to manufacture). Each facility } \\
\text { should improve their productivity and efficiency (total productive } \\
\text { maintenance (TPM)). }\end{array}$ \\
\hline
\end{tabular}

\subsubsection{Information Indicators}

The information indicators are analyzed in Table 22 to identify potential improvements regarding the coordination of information and material flows.

Table 22. Identification of bottlenecks based on the information indicators and suggestions to overcome these bottlenecks.

\begin{tabular}{ll}
\hline & $\begin{array}{l}\text { OP5 has the most considerable relative variance in the supply chain. This } \\
\text { uncertainty weakens the production performance of the Ronneby S.U. } \\
\text { factory, leading to organizational losses-it requires re-scheduling and } \\
\text { forces the Ronneby S.U. factory to keep a large inventory. It would be } \\
\text { Time (VLT) } \\
\text { fluctuations. If not possible, the Ronneby S.U. factory should look for a } \\
\text { new supplier to ensure a steady flow of raw materials. }\end{array}$ \\
& $\begin{array}{l}\text { OP7 is the most critical path with regard to material distortion. The } \\
\text { after-market seems to be an unsteady market, so many unforeseen } \\
\text { deviations trigger rush orders, causing a malfunction in the supply chain. } \\
\text { Two options are suggested to improve information performance: (i) to } \\
\text { implement a vendor-managed inventory (currently the costumer } \\
\text { production control sends orders to the Ronneby production control, } \\
\text { (BE) } \\
\text { Figure 3); and (ii) to increase the inventory units in the distribution center } \\
\text { to protect it against the uncertainties of the market demand. }\end{array}$ \\
\hline
\end{tabular}

\subsubsection{Environmental Indicators}

The environmental indicators are assessed and discussed in Table 23 to identify the bottlenecks regarding the supply chain's environmental performance. 
Table 23. Identification of bottlenecks based on the environmental indicators, and suggestions to overcome these bottlenecks.

\begin{tabular}{ll}
\hline & $\begin{array}{l}\text { OP9 has the most considerable carbon footprint in the supply chain. The } \\
\text { transportation flow from the Italy S.U. has a significant impact on the CE; } \\
\text { (CE) } \\
\text { thereby, it is strongly recommended to adopt the solution mentioned } \\
\text { above. Apart from moving the supply unit's production, it is suggested to } \\
\text { improve the equipment efficiency, especially the vehicles that account for } \\
\text { the largest share of carbon emissions (see Table 15). }\end{array}$ \\
& $\begin{array}{l}\text { OP9 is again identified as the bottleneck in terms of material waste. This } \\
\text { fact supports the conclusions drawn in the EC, TLF, IT and WF indicators. } \\
\text { An additional critical factor which significantly impacts the waste } \\
\text { generation is the production performance in terms of quality. The higher } \\
\text { the scrap, the higher the waste. Hence, quality improvement should also } \\
\text { reduce the supply chain's environmental impact. }\end{array}$ \\
& $\begin{array}{l}\text { OP6 and OP8 do not consume any renewable energy. Analyzing the } \\
\text { indicators and the related data, two concerns appear: (i) Italy's factory is } \\
\text { the only one that does not use renewable energy; and (ii) all transport } \\
\text { energy comes from fossil energy. Due to the fact that transport represents a } \\
\text { significant share of the energy consumption, it is required to (i) reduce the } \\
\text { transport in the supply chain (adds value to the customer); and (ii) invest } \\
\text { in "greener" means of transportation (e.g., hybrid vehicles or trains). }\end{array}$ \\
\hline Sustainable Energy &
\end{tabular}

\subsubsection{Social Indicators}

Finally, to achieve a more socially sustainable supply chain, the social indicators are analyzed to improve its performance. They are presented and discussed in Table 24.

Table 24. Identification of bottlenecks based on the social indicators, and suggestions to overcome these bottlenecks.

OP8 and OP7 are the most critical paths with regard to labor equity. This means that they report the most significant differences between the lowest Labor Equity (LE) and highest salaries (EUR $26 \mathrm{k}$ and EUR $84 \mathrm{k}$ ) of the supply chain. Raising the lowest wage should be on the supply chain management agenda to reduce the gap of wealth distribution and, in this way, increase the workers' motivation.

OP3 has the worst performance regarding corruption. All entities of this path have broken the law, as well as dismissed the business ethic code. It represents a non-sustainable social performance that would probably Corruption (C) damage the entire supply chain and its image. Therefore, measures must be implemented to raise awareness among workers about the importance of fair competition. Additionally, an internal audit program would help to review the current standards to decrease these figures significantly.

OP7 is reported as having the highest fatal accident rate in the supply chain. This path is the most dangerous, and workers are prone to suffer an

Fatal Accident Rate (FAR) accident while carrying out their tasks. This must be considered as unacceptable for all the companies. Enhancing workforce protection policies and raising awareness among workers must be a priority in order to reduce the number of accidents.

The presented indicators point out all the significant supply chain bottlenecks. The indicators provide sufficient and adequate information to guide the development of the future state of EVSM. It is important to note that, as presented in Figure 5, OP9 is the one that shows the highest number of critical points. Therefore, the recommendation is that this path should be the one to be tackled first. 


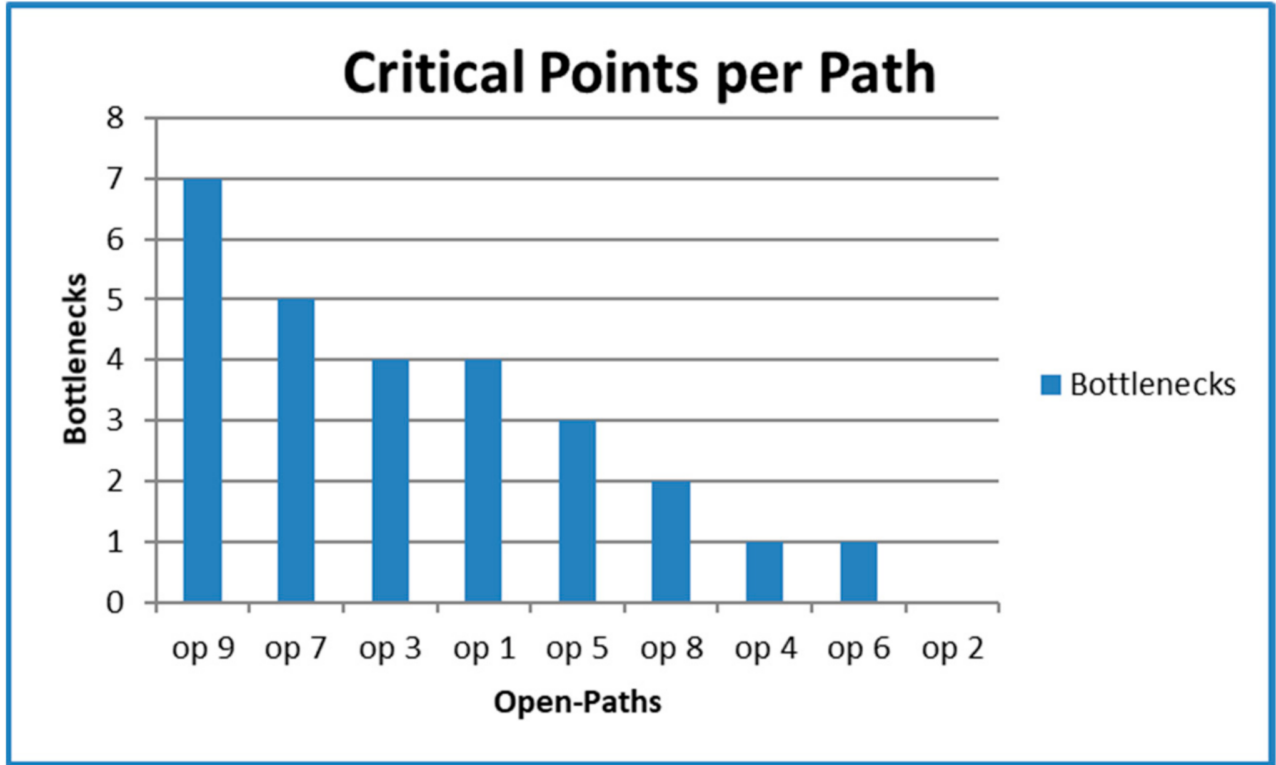

Figure 5. Critical points identified per open path.

In summary, the main outcomes/achievements of applying the SustainSC-VSM methodology to the case study are as follows:

(i) It leads to the identification of hot spots (e.g., flow of steel from supplier to the component unit in Ronneby and its transport to the Ronneby supply unit seem to be a critical point due to high levels of inventory);

(ii) It provides suggestions to overcome these hot spots (e.g., change current MTS policy to MTO in order to reduce unnecessary inventory);

(iii) It guides the user towards the development of the future state of the value stream map based on the suggestions provided, allowing the development of a more sustainable supply chain.

\section{Conclusions}

A novel methodology (SustainSC-VSM) is proposed in this work and it aims at being a systematic tool to design the future value stream map that will support the attainment of a (more) sustainable supply chain. This follows a lean-driven sustainability approach where a set of indicators is used to identify and solve the supply chain's bottlenecks. SustainSCVSM is based upon: (i) the lean viewpoint of zero wastes, smooth flow and adding value for the customer; (ii) the sustainability concepts, cutting the use of unnecessary resources; and (iii) the coordination of information to improve overall performance. Furthermore, guidelines to tackle the bottlenecks identified are also given. This methodology was tested and validated through its application to a relevant and real industrial case study. The indicators provided sufficient and adequate information to guide the user through the identification of the bottlenecks, and along with the provided recommendations, it was possible to derive the future state of the value stream map. Therefore, SustainSC-VSM proved to be an efficient tool to enhance the overall supply chain's performance and sustainability.

SustainSC-VSM has many managerial benefits. (a) It allows visually mapping the operations of the supply chain in a sustainable perspective. (b) It turns VSM into being applicable to supply chains and increases the confidence in the bottlenecks' identification. VSM is usually a visual and qualitative tool and SustainSC-VSM allows the decision makers, through a set of indicators, to clearly identify and prioritize actions towards a more sustainable supply chain. (c) Decision makers can use SustainSC-VSM in any sector and easily eliminate indicators that do not fit their purposes or add additional indicators that are relevant for their core business. (d) SustainSC-VSM decomposes complex supply 
chains in paths, which allows managers to clearly identify problems in complex systems, which are usually not comprehensive due to their complexity. (e) The proposed indicators are also a powerful tool for supply chain managers to quantify the improvements they have made. This will allow them to monitor their sustainability performance and also to communicate internally and with their stakeholders about the improvements achieved.

Although validated on a manufacturing case study, the proposed methodology is flexible and adaptable to other industries and sectors. Suggestions for further research include the analysis of additional case studies, so that some additional guidelines can be developed for the inclusion or exclusion of indicators according to the type of supply chain (service-based, chemical-based, etc.). Moreover, multicriteria decision analysis methodologies could be employed in order to explore potential trade-offs among indicators. This would provide a simpler way to communicate with the decision maker.

Author Contributions: C.L.G.: Methodology validation, writting and revision, E.P.P.: Methodology development, case study application, writting, A.P.B.-P.: revising and supervision A.C.: Methodology development, case study application, writting, revising and supervision. All authors have read and agreed to the published version of the manuscript.

Funding: This research received no external funding.

Institutional Review Board Statement: Not applicable.

Informed Consent Statement: Not applicable.

Data Availability Statement: Not applicable.

Conflicts of Interest: The authors declare no conflict of interest.

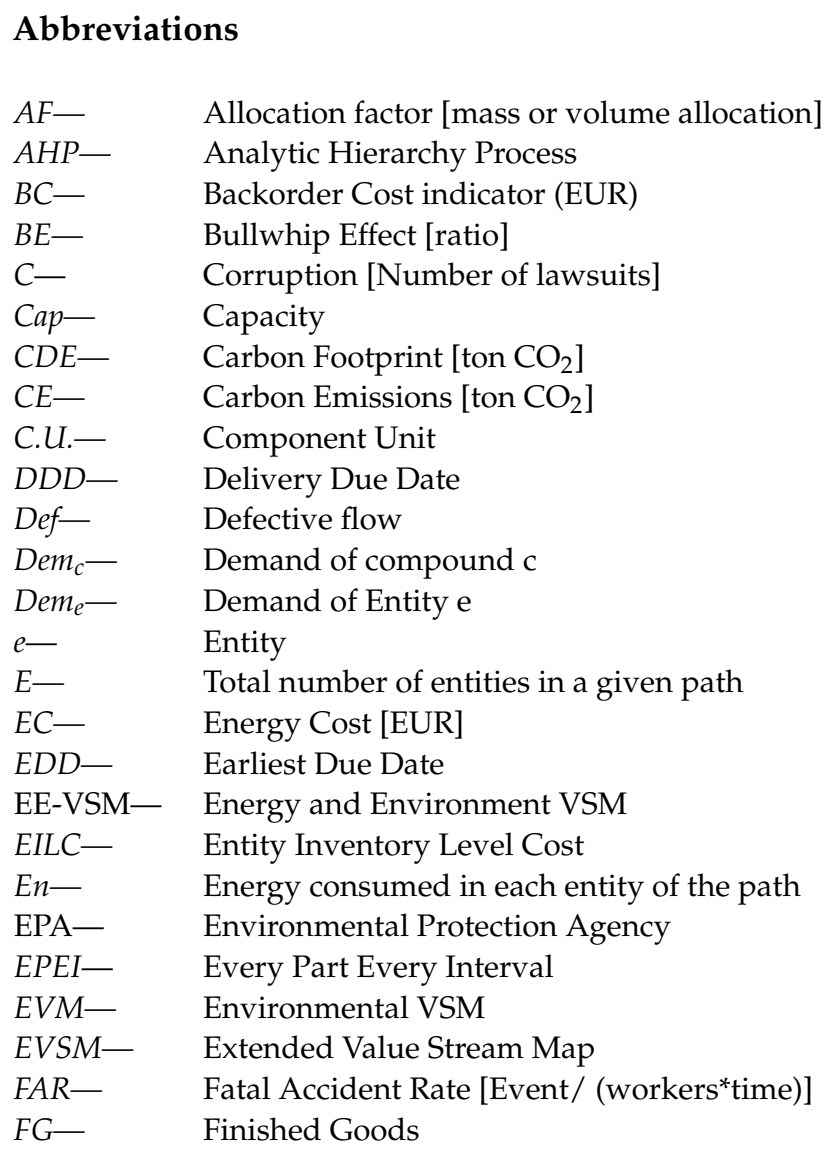




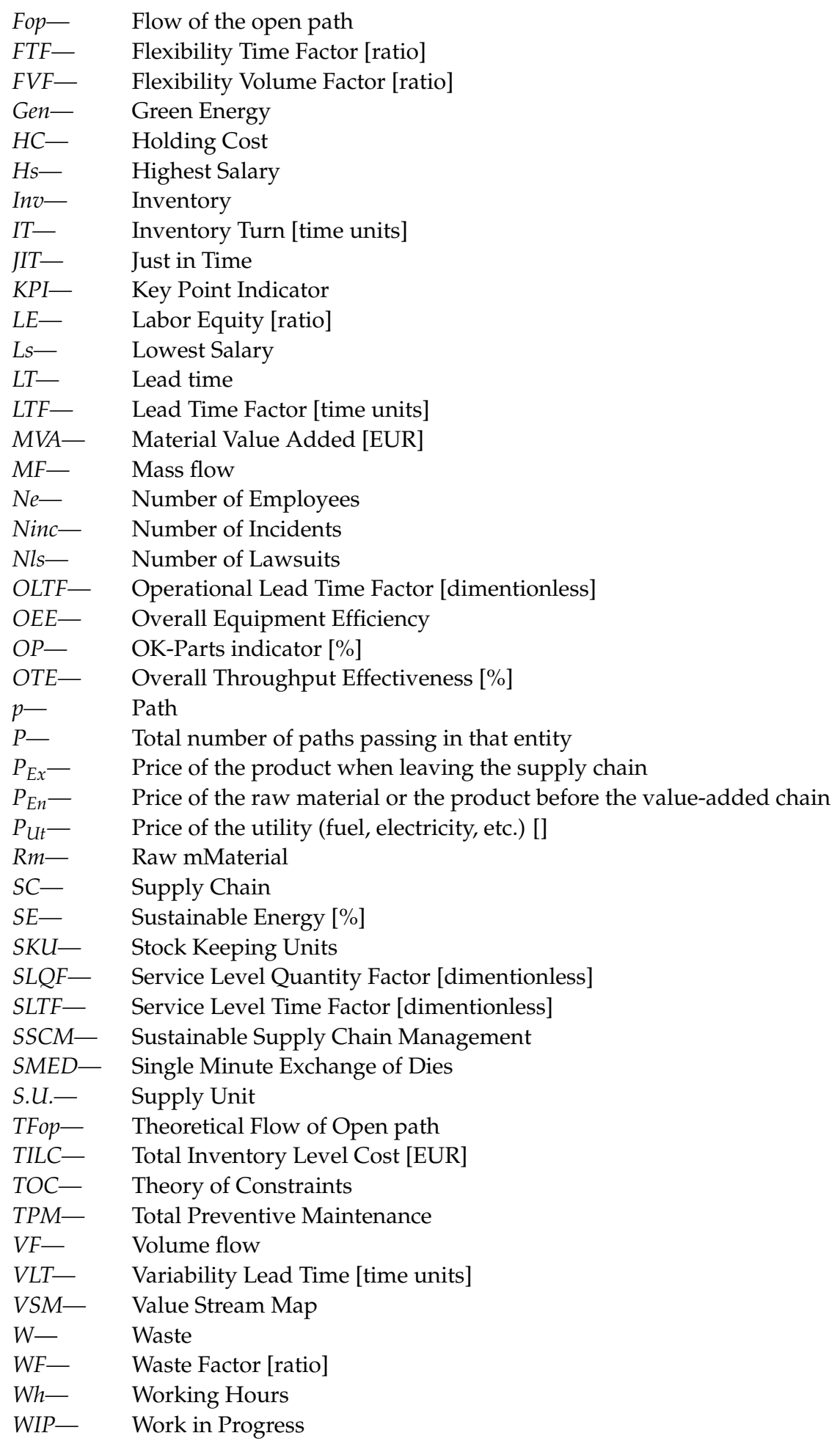




\section{Appendix A. Indicators}

Table A1. Summary of all indicators proposed in the SustainSC-VSM methodology.

\begin{tabular}{|c|c|c|}
\hline Indicator & Description & Units \\
\hline Material Value Added & Value added in the supply chain per path & Euro \\
\hline Energy Cost & The cost of energy consumption per path & Euro \\
\hline Total Inventory Level Cost & The cost of the inventory per path & Euro \\
\hline Entity Inventory Cost & The percentage of cost that represents each entity & Ratio \\
\hline Backorder & The total value of lost sales per path & Euro \\
\hline Lead Time Factor & The total lead time per path & Time \\
\hline Operational Lead Time Factor & The percentage of time that represents each entity & Ratio \\
\hline Inventory Turns & The inventory that takes longer to empty per path & Time \\
\hline Service Level Quantity Factor & The accomplishment of the delivered quantity per path & Ratio \\
\hline Service Level Time Factor & The accomplishment of the delivered time per path & Ratio \\
\hline OK-Parts & The quality of the delivered product per path & Percentage \\
\hline Overall throughout effectiveness & Comparing actual to maximum attainable productivity p.e.p. & Percentage \\
\hline Volume Flexibility & The capacity to adapt to volume demand changes per path & Ratio \\
\hline Time Flexibility & The capacity to adapt to time demand changes per path & Ratio \\
\hline Carbon Emission & The $\mathrm{CO}_{2}$ emissions into the environment per path & Tons $\mathrm{CO}_{2}$ \\
\hline Waste Factor & The disposal of waste material per path & Ratio \\
\hline Sustainable Energy & The ratio of renewable energy used per path & Percentage \\
\hline Labor Equity & The distribution of employee compensation per path & Ratio \\
\hline Fatal Accident Rate & Statistical method that reports the number of incidents per path & Inc $/\left(\mathrm{Em}^{*}\right.$ Time $)$ \\
\hline Corruption & The total number of lawsuits per path & Lawsuits \\
\hline Variability of lead time & The variability of the Lead Time Factor per path & Time \\
\hline Bullwhip Effect & The demand variation of the first entity per path & Ratio \\
\hline
\end{tabular}

\section{Appendix B. Data Collection}

The following data are composed of the information collected in order to apply the SustainSC-VSM methodology to the presented case study.

Price of Utilities: For entities, the data were obtained from (https:/ / www.argusmedia. com/metals-platform/priceindex) (accessed on 24 February 2021). for European electricity prices and from (https://www.eia.gov/electricity/monthly/epm_table_grapher.php?t= epmt_5_03) for the USA electricity price (accessed on 24 February 2021). For transport flows, the fuel (gasoline) prices come from (http:/ / www.globalpetrolprices.com) (accessed on 24 February 2021).

Energy Consumption: The consumption was estimated from the annual report (92.381 MWh) and the Alfa Laval ratio (EUR 1 million of value added/300 MWh) [67]. For transport flows, the energy consumption was determined assuming the average fuel consumption of a truck $(17.41 / 100 \mathrm{~km})$ [70].

Holding Cost: The holding cost was estimated considering the premise: the more complex the component, the higher the cost, and from the annual figures of the inventory cost (SEK 258 million) [67].

Green Energy: For entities, the consumption of green energy was estimated from the annual report of the company (827 MWh) [67]. The annual report figures consider all the divisions of Alfa Laval; therefore, the data are just a fraction of the report figures. For transport flows, it was assumed that all the trucks are gasoline engine vehicles; therefore, the green energy is estimated as 0 in all the transport paths.

Employees: The number of employees was estimated from the annual report figures of the company [67]. The annual report figures consider all the divisions of Alfa Laval (16.468 employees); therefore, the data are just a fraction of the total number. In the allocation of employees in each factory, the amount of flow and the nature of the entity were considered. For example, a factory requires more employees than a distribution center.

Capacity: The process capacity of each facility was estimated from the data of the demand. The higher the demand for an entity, the higher the process capacity of the entity.

Carbon Footprint: For entities, the carbon footprint of the entities was estimated using two sources of information:

- The annual report (34.440 tons $\mathrm{CO}_{2}$ manufacturing) [67]; 
- The ratio between transport and production emissions (49.777 tons $\mathrm{CO}_{2}$ transport/ 34.440 tons $\mathrm{CO}_{2}$ manufacturing) [67].

For transport flow, the data of the carbon footprint were estimated using the ratio $\left(105.5 \mathrm{~g} /\left(\right.\right.$ tonne $\left.\left.^{*} \mathrm{~km}\right)\right)$ [67].

Waste:

The defective flows are all the parts/final products that had quality problems and that, therefore, will be waste. Waste is considered as all the parts and final products that are not able to be reprocessed and all other material flows of production or packaging that will be waste. Therefore, waste includes the defective flows.

For entities, the waste was determined adding the defective flow and a complementary mass flow of material disposal which was assumed, since there were no data available.

For transport flows, the waste values match with the defective flow values because the only source of waste is the defects that may occur during the transport. Packaging waste has not been considered.

Lawsuits, Salaries and Incidents: The number of lawsuits, the salaries and the numbers of incidents were assumed, since there were no data available. The number of incidents makes reference to major injury accidents.

Working Hours: Finally, the number of worked hours per year was obtained from (https:/ / data.oecd.org/emp/hours-worked.htm) (accessed on 24 February 2021).

Price of Product and Raw Materials: The price of the steel and copper is from (https:/ / www.argusmedia.com/metals-platform/priceindex) (accessed on 24 February 2021). The final price of the heat exchanger was estimated from an Alfa Laval catalogue (https:/ / pdf.directindustry.com/pdf/alfa-laval/heating-cooling-systems /16602769212.html) (accessed on 24 February 2021).

Customer Demand, On-Time Flow and Theoretical Flow: The customer demand, the on-time flow and theoretical flow were estimated from the values of the flow of each path.

Delivery Due Date and Earliest Due Date: The delivery and earliest due dates were estimated from the Lead Time Factor.

Variance of Lead Time, Demand and Flow Path: The variances of lead time, demand and flow path were assumed since there were no data available. The mean value was used as a reference on the assumptions.

Open Paths:

Price of Product and Raw Materials: The price of the steel and copper is from (https: / / www.argusmedia.com/metals-platform/priceindex) (accessed on 24 February 2021).

The final price of the heat exchanger was estimated from an Alfa Laval catalogue (https: / / pdf.directindustry.com/pdf/alfa-laval/heating-cooling-systems/16602-769212.html) (accessed on 24 February 2021).

Customer Demand, On-Time Flow and Theoretical Flow: The customer demand, the on-time flow and theoretical flow were estimated from the values of the flow of each path.

Delivery Due Date and Earliest Due Date: The delivery and earliest due dates were estimated from the Lead Time Factor.

Variance of Lead Time, Demand and Flow Path: The variances of lead time, demand and flow path were assumed since there were no data available. The mean value was used as a reference on the assumptions.

\section{References}

1. Tasdemir, C.; Gazo, R. A systematic literature review for better understanding of lean driven sustainability. Sustainability 2018, 10, 2544. [CrossRef]

2. Dey, M.; LaGuardia, A.; Srinivasan, P. Building Sustainability in Logistics Operations: A Research Agenda. Manag. Res. Rev. 2011, 34, 1237-1259. [CrossRef]

3. Wilson, L. How to Implement Lean Manufacturing; McGraw-Hill: New York, NY, USA, 2010.

4. Zakery, A. Logistics Future Trends. In Logistics Operations and Managemen; Elsevier: Amsterdam, The Netherlands, 2011; pp. 93-105.

5. Battor, M.; Battor, M. The impact of customer relationship management capability on innovation and performance advantages: Testing a mediated model. J. Mark. Manag. 2010, 26, 842-857. [CrossRef] 
6. Stank, R.; Autry, T.; Bell, C.; Gilgor, J.; Petersen, D.; Dittmann, K.; Moon, P.; Tate, M.; Bradley, W. Game-Changing Trends in Supply Chain; Haslam College of Business: Knoxville, TN, USA, 2013.

7. Council of Supply Chain Management Professionals (CSCMP). Council of Supply Chain Management Professionals-Terms and Glossary; CSCMP: Chicago, IL, USA, 2013.

8. Vonderembse, M.A.; Uppal, M.; Huang, S.H.; Dismukes, J.P. Designing supply chains: Towards theory development. Int. J. Prod. Econ. 2006, 100, 223-238. [CrossRef]

9. Linton, J.D.; Klassen, R.; Jayaraman, V. Sustainable supply chains: An introduction. J. Oper. Manag. 2007, 25, 1075-1082. [CrossRef]

10. Winch, J.K. Supply Chain Management: Strategy, Planning, and Operation. Int. J. Qual. Reliab. Manag. 2003, 20, 398-400. [CrossRef]

11. Tăucean, I.; Tămășilă, M.; Ivascu, L.; Miclea, Ș.; Negrut, M. Integrating Sustainability and Lean: SLIM Method and Enterprise Game Proposed. Sustainability 2019, 11, 2103. [CrossRef]

12. Jones, D.T.; Womack, J.P. Seeing the Whole: Mapping the Extended Value Stream; Lean Enterprise Institute: Brookline, MA, USA, 2002.

13. Carvalho, A.; Matos, H.A.; Gani, R. SustainPro-A tool for systematic process analysis, generation and evaluation of sustainable design alternatives. Comput. Chem. Eng. 2013, 50, 8-27. [CrossRef]

14. Hartini, S.; Ciptomulyono, U.; Anityasari, M. Extended value stream mapping to enhance sustainability: A literature review. AIP Conf. Proc. 2017, 020030. [CrossRef]

15. Lindo-Salado-Echeverría, C.; Sanz-Angulo, P.; De-Benito-Martín, J.J.; Galindo-Melero, J. Aprendizaje del Lean Manufacturing mediante Minecraft: Aplicación a la herramienta 5S. RISTI Rev. Ibérica Sist. Tecnol. Inf. 2015. [CrossRef]

16. Soltero, C.; Waldrip, G. Using Kaizen to Reduce Waste and Prevent Pollution. Environ. Qual. Manag. 2002, 11, 23-38. [CrossRef]

17. Womack, J.P. Value stream mapping. Manuf. Eng. 2006, 136, 145.

18. Haefner, B.; Kraemer, A.; Stauss, T.; Lanza, G. Quality Value Stream Mapping. Procedia CIRP 2014, 17, 254-259. [CrossRef]

19. McKellen, C. Pull and kanbans [production control]. Metalwork. Prod. 2004, 148, 16.

20. Biotto, C.; Mota, B.; Araújo, L.; Barbosa, G.; Andrade, F. Adapted use of andon in a horizontal residential construction project. In Proceedings of the 22nd Annual Conference of the International Group for Lean Construction: Understanding and Improving Project Based Production, Oslo, Norway, 25-27 June 2014; pp. 1295-1605.

21. Jain, A.; Bhatti, R.; Singh, H. Total productive maintenance (TPM) implementation practice. Int. J. Lean Six Sigma 2014, 5, 293-323. [CrossRef]

22. Rahayu, A. Implementasi Single Minute Exchange of Dies (Smed) Untuk Perbaikan Proses Brand Changeover Mesin Focke Dan Protos. Ind. Xplore 2020, 5, 8-16. [CrossRef]

23. Talekar, A.A.; Patil, S.Y.; Shinde, P.S.; Waghmare, G.S. Setup time reduction using single minute exchange of dies (SMED) at a forging line. AIP Conf. Proc. 2019, 020018. [CrossRef]

24. Da Silva, M.G. Jidoka: Concepts and application of autonomation in an electronics industry company. Espacios $2016,37$.

25. Rothenberg, S.; Pil, F.K.; Maxwell, J. Lean, green, and the quest for superior environmental performance. Prod. Oper. Manag. 2001, 10, 228-243. [CrossRef]

26. Faulkner, W.; Badurdeen, F. Sustainable Value Stream Mapping (Sus-VSM): Methodology to visualize and assess manufacturing sustainability performance. J. Clean. Prod. 2014, 85, 8-18. [CrossRef]

27. Mishra, A.K.; Sharma, A.; Sachdeo, M.; Jayakrishna, K. Development of sustainable value stream mapping (SVSM) for unit part manufacturing. Int. J. Lean Six Sigma 2019, 11, 493-514. [CrossRef]

28. Djatna, T.; Prasetyo, D. Integration of Sustainable Value Stream Mapping (Sus. VSM) and Life-Cycle Assessment (LCA) to Improve Sustainability Performance. Int. J. Adv. Sci. Eng. Inf. Technol. 2019, 9, 1337. [CrossRef]

29. Ikatrinasari, Z.F.; Hasibuan, S.; Kosasih, K. The Implementation Lean and Green Manufacturing through Sustainable Value Stream Mapping. IOP Conf. Ser. Mater. Sci. Eng. 2018, 453, 012004. [CrossRef]

30. Muñoz-Villamizar, A.; Santos, J.; Garcia-Sabater, J.J.; Lleo, A.; Grau, P. Green value stream mapping approach to improving productivity and environmental performance. Int. J. Product. Perform. Manag. 2019, 68, 608-625. [CrossRef]

31. Torres, A.S.; Gati, A.M. Environmental Value Stream Mapping (EVSM) as sustainability management tool. In Proceedings of the PICMET '09-2009 Portland International Conference on Management of Engineering \& Technology, Portland, OR, USA, 2-6 August 2009; pp. 1689-1698. [CrossRef]

32. Verma, N.; Sharma, V. Energy Value Stream Mapping a Tool to Develop Green Manufacturing. Procedia Eng. 2016, 149, 526-534. [CrossRef]

33. Dombrowski, U.; Riechel, C.; Ernst, S. Energy Value Stream Mapping as a Tool of the Digital Factory-Sustainable Optimization with Simulative Energy Value Stream Mapping. Ind. Manag. 2012, 55-58.

34. United States Environmental Protection Agency (EPA). The Lean E Energy Toolkit; EPA: Washington, DC, USA, 2019.

35. United States Environmental Protection Agency (EPA). The Lean and Environment Toolkit; EPA: Washington, DC, USA, 2007.

36. Carvalho, A.; Gani, R.; Matos, H. Design of sustainable chemical processes: Systematic retrofit analysis generation and evaluation of alternatives. Process Saf. Environ. Prot. 2008, 86, 328-346. [CrossRef]

37. Carvalho, A.; Gani, R.; Matos, H. Design of Sustainable Chemical Processes: Systematic Retrofit Analysis, Generation and Evaluation of Alternatives; Instituto Superior Tecnico: Lisbon, Portugal; Denmark Technical University: Copenhagen, Denmark, 2009.

38. Mah, R.S. Application of graph theory to process design and analysis. Comput. Chem. Eng. 1983, 7, 239-257. [CrossRef]

39. Beamon, B.M. Measuring supply chain performance. Int. J. Oper. Prod. Manag. 1999, 19, 275-292. [CrossRef] 
40. Shepherd, C.; Günter, H. Measuring supply chain performance: Current research and future directions. Int. J. Product. Perform. Manag. 2006, 55, 242-258. [CrossRef]

41. Bolstorff, P. Measuring the impact of supply chain performance. CLO Chief Logist. Off. 2003, 12, 11.

42. Gunasekaran, A.; Patel, C.; McGaughey, R.E. A framework for supply chain performance measurement. Int. J. Prod. Econ. 2004, 87, 333-347. [CrossRef]

43. Angerhofer, B.J.; Angelides, M.C. A model and a performance measurement system for collaborative supply chains. Decis. Support Syst. 2006, 42, 283-301. [CrossRef]

44. Jammernegg, W.; Reiner, G. Performance improvement of supply chain processes by coordinated inventory and capacity management. Int. J. Prod. Econ. 2007, 108, 183-190. [CrossRef]

45. U.S. Department of Transportation. US Department of Transportation, 2002; U.S. Department of Transportation: Washington, DC, USA, 2002.

46. Ye, T. Inventory management with simultaneously horizontal and vertical substitution. Int. J. Prod. Econ. 2014, 156, 316-324. [CrossRef]

47. Liao, T.W.; Chang, P.C. Impacts of forecast, inventory policy, and lead time on supply chain inventory-A numerical study. Int. J. Prod. Econ. 2010, 128, 527-537. [CrossRef]

48. Lee, H.L.; Padmanabhan, V.; Whang, S. Information Distortion in a Supply Chain: The Bullwhip Effect. Manag. Sci. 2004, 50, 1875-1886. [CrossRef]

49. Rother, M.; Shook, J. Lean Enterprise Institute. In Learning to See: Value Stream Mapping to Create Value and Eliminate Muda; Lean Enterprise Institute: Boston, MA, USA, 2003.

50. Soltani, E.; Azadegan, A.; Liao, Y.Y.; Phillips, P. Quality performance in a global supply chain: Finding out the weak link. Int. J. Prod. Res. 2011, 49, 269-293. [CrossRef]

51. Giri, B.C.; Sharma, S. Optimizing a closed-loop supply chain with manufacturing defects and quality dependent return rate. $J$. Manuf. Syst. 2015, 35, 92-111. [CrossRef]

52. Buchmeister, B.; Friscic, D.; Lalic, B.; Palcic, I. Analysis of a Three-Stage Supply Chain with Level Constraints. Int. J. Simul. Model. 2012, 11, 196-210. [CrossRef]

53. Muthiah, K.M.N.; Huang, S.H. Overall throughput effectiveness (OTE) metric for factory-level performance monitoring and bottleneck detection. Int. J. Prod. Res. 2007, 45, 4753-4769. [CrossRef]

54. Nakajima, S. Introduction to TPM: Total Productive Maintenance; Productivity Press: Boca Raton, FL, USA, 1988.

55. Das, S.K.; Abdel-Malek, L. Modeling the flexibility of order quantities and lead-times in supply chains. Int. J. Prod. Econ. 2003, 85, 171-181. [CrossRef]

56. Chaabane, A.; Ramudhin, A.; Paquet, M. Design of sustainable supply chains under the emission trading scheme. Int. J. Prod. Econ. 2012, 135, 37-49. [CrossRef]

57. Mimoso, A.F.; Carvalho, A.; Mendes, A.N.; Matos, H.A. Roadmap for Environmental Impact Retrofit in chemical processes through the application of Life Cycle Assessment methods. J. Clean. Prod. 2015, 90, 128-141. [CrossRef]

58. Mintcheva, V. Indicators for environmental policy integration in the food supply chain (the case of the tomato ketchup supply chain and the integrated product policy). J. Clean. Prod. 2005, 13, 717-731. [CrossRef]

59. Popovic, T.; Barbosa-Póvoa, A.; Kraslawski, A.; Carvalho, A. Quantitative indicators for social sustainability assessment of supply chains. J. Clean. Prod. 2018, 180, 748-768. [CrossRef]

60. Hutchins, M.J.; Sutherland, J.W. An exploration of measures of social sustainability and their application to supply chain decisions. J. Clean. Prod. 2008, 16, 1688-1698. [CrossRef]

61. Roberts, S.E. Britain's most hazardous occupation: Commercial fishing. Accid. Anal. Prev. 2010, 42, 44-49. [CrossRef] [PubMed]

62. Sabato, M.; Bruccoleri, L. The Relationship between Bullwhip Effect and Lead Times Variability in Production-Distribution Networks. 2005. Available online: https:/ / pure.unipa.it/it/publications/the-relationship-between-bullwhip-effect-and-leadtimes-variabili-2 (accessed on 1 March 2021).

63. Chen, F.; Drezner, Z.; Ryan, J.K.; Simchi-Levi, D. Quantifying the bullwhip effect in a simple supply chain: The impact of forecasting, lead times, and information. Manag. Sci. 2000, 46, 436-443. [CrossRef]

64. Persson, F. SCOR template-A simulation based dynamic supply chain analysis tool. Int. J. Prod. Econ. 2011, 131, 288-294. [CrossRef]

65. Bradstreet, D. ALFA LAVAL SPA Company Profile. 2021. Available online: https://www.dnb.com/business-directory/companyprofiles.alfa_laval_spa.501f128743daf278bb2b98eafd02e422.html (accessed on 1 March 2021).

66. AlfaLaval. Alfa Laval Partner Days. 2018. Available online: https://www.alfalaval.com/globalassets/images/misc/ partnerdays/alfalavalpartnerdays2018-programme.pdf (accessed on 1 March 2021).

67. Alfa Laval. Alfa Laval Sustainability GRI Report; Alfa Laval: Lund, Sweden, 2014.

68. Lucidchart. "Lucidchart." (C) 2021 Lucid Software Inc. 2021. Available online: https://www.lucidchart.com/pages/examples/ value-stream-mapping-software (accessed on 1 March 2021).

69. Carvalho, A.; Matos, H.A.; Gani, R. Design of batch operations: Systematic methodology for generation and analysis of sustainable alternatives. Comput. Chem. Eng. 2009, 33, 2075-2090. [CrossRef]

70. Davis, S.C.; Boundy, R.G. Transportation Energy Data Book, 39th ed.; Oak Ridge National Laboratory, U.S. Department of Energy, Office of Science: Oak Ridge, TN, USA, 2021. 